\title{
BYRONS PERSÖNLICHE UND GEISTIGE BEZIEHUNGEN ZU DEN GEBIETEN DEUTSCHER KULTUR.
}

Hauptsächliche literaturangaben.

Ackermann, Lord Byron, 1901.

Bädekers Rheinlande. Schweiz.

Blessington, Lady, A Journal of the Conversations of Lord Byron. 1893.

Brandl, A., Goethe und Byron. Oesterr. Rundschau, I; 1883.

Brandl, A., Goethes Verhältnis zu Byron. Goethe-Jahrbuch, XX; 1899.

Broughton, Lord (J. C. Hobhonse), Recollections of a Long Life. Ed. by Lady Dorchester. I-IV. 1909.

B yron, Poetical Works, ed. E. H. Coleridge, I-VII, $1903 \mathrm{ff}$.

Byron, Letters and Journals, ed. R. E. Prothero, I-VI, $1902 \mathrm{ff}$.

Eberty, Lord Byron. 1862.

Elze, Lord Byron. 1886.

Gamba, A Narrative of Lord Byron's Last Journey to Greece. 1825.

Hunt, Lord Byron and some of his Contemporaries, etc., I. 1828.

Kennedy, Conversations on Religion with Lord Byron. 1830.

Koeppel, Lord Byron. 1903.

Kn obbe, A., Die Faust-Idee in Lord Byrons Dichtungen. 1906.

Kraeger, Der Byronsche Heldentypus. 1898.

Lee, S. and H., Canterbury Tales. 1832.

Medwin, Journal of the Conversations of Lord Byron, I. II; 1825.

M o ore, Notices on the Life of Lord Byron. Band IV der Select Works, 1833.

Polid ori, J. W., 'The Diary, 1816. Ed. W. M. Rossetti. 1911.

Schaffner, Lord Byron's Cain und seine Quellen. 1880.

Schröer, A., Grundzüge und Haupttypen der Engl. Literaturgeschichte.

II. 2. Aufl. 1911.

Shelley, P. B., Works, ed. H. Buxton Forman. 1880.

Sinzheimer, Goethe und Byron. 1894.

Stä̈l, Me de, Oeurres complètes, I-XVII; 1821.

Varn hag en, H., Über Byrons ... "Der umgestaltete Mirsgestaltete". 1905. 


\section{Abkürzungen.}

G.-J. = Goethe-Jahrbuch XX. (Brandl).

L. J. = Letters and Journals (Byron), ed. Prothero.

Ö. R. = Oesterreichische Rundschau I (1883; Brandl).

Poetry $=$ Poetical Works (Byron), ed. E. H. Coleridge.

Die übrigen (z. b. Ch. H. = Childe Harold; D. J. = Don Juan) ergeben sich von selbst.

\section{Vorbemerkung.}

In der vorliegenden Byronstudie habe ich versucht, alles zusammenzufassen, was Byrons persönliche und geistige beziehungen zu Deutschland, Österreich und der deutschen Schweiz betrifft, und zwar geordnet nach folgenden gesichtspunkten:

I. Persönliche erfahrungen und eindrücke.

1. Die sprache. - 2. Persönliche bekanntschaften. -

3. Urteile über deutsche art, die deutsche Schweiz und die Österreicher. - 4. Reise am Rhein und ins Berner Oberland.

II. Geistige beziehungen.

1. Byrons kenntnisse von deutscher geographie, geschichte und musik. - 2. Kenntnisse von der deutschen literatur (aufser Goethe). - 3. Byrons kenntnisse von seinem berühmtwerden in Deutschland und von Goethes wertschätzung. -4 . Kenntnis von Goethes werken und bewunderung seines genius. - 5. Goethes einflufs auf Byrons werke. -

Abschnitt I ist in ähnlicher weise noch nicht behandelt worden; die Rheinreise, über die wir nun durch Polidoris Diary genauer unterrichtet sind, ist stets sehr kurz weggekommen und die Oberlandreise auf einzelheiten hin noch nicht genauer nachgeprüft worden; Kraegers versuch ist z. tl. fehlerhaft.

$\mathrm{Zu}$ abschnitt $\mathrm{II}, 1-2$, ist zu sagen, daIs er allerhand neue einzelheiten enthält, und dals namentlich Byrons verhältnis zu Schiller möglichst genau zusammengefafst wird: Kraeger und Knobbe sind nicht erschöpfend.

II, 3-5, mögen auf den ersten blick überflüssig erscheinen. Aber bis jetzt ist nur "Goethe und Byron" genauer behandelt 
worden (Brandl, Sinzheimer), nicht aber "Byron und Goethe", abgesehen von summarischen überblicken (z. b. von J. Werner; Berichte des Freien Deutschen Hochstifts zu Frankfurt, 1885/6. S. $181 \mathrm{ff})$. Auch Knobbes vielfach scharfsinnige und eingehende untersuchungen, die sich auch auf Byrons verhältnis zur deutschen literatur überhaupt erstrecken, konnten verschiedentlich ergänzt und erweitert werden. Auch zur frage nach der abhängigkeit Byrons von Goethes Faust konnten noch allerhand bemerkungen gemacht werden, abgesehen von der, wie ich hoffe, erschöpfenden darbietung der briefstellen usw., wo Byron sich selbst darüber äufsert. Auch die frage wegen Know ye the land ist noch genauer ergründet worden, als Knobbe es schon tat. -

Vieles, was sich in dieser studie findet, ist dem fachmann wohlbekannt. Ich habe aber dennoch geglaubt, es nicht übergehen zu sollen, sondern den stoff so zu formen, dals auch solche, die etwa weniger vertraut damit wären, ein abgerundetes bild von Byrons verhältnis zu Deutschland usw. vorfinden.

\section{I.}

Persönliche erfahrungen und eindrücke.

\section{Die sprache.}

Byrons beziehungen zur deutschen kultur blieben für ihn zeit seines lebens sehr erschwert durch seine unkenntnis der deutschen sprache. Wie in so vielem anderen war Byron zwar auch darin kein typischer Brite, dafs er sprachen mit leichtigkeit lernte und anwandte, ja, sogar interesse dafür hatte. Aber das Deutsche blieb ihm fremd, obwohl er es auf der schule in Aberdeen zu lernen angefangen hatte. Er selbst berichtet darüber in der vorrede zu Cain:

Gesner's "Death of Abel" I have never read since I was eight years of age, at Aberdeen.

Und Thomas Medwin lälst ihn mitteilen (I, s. 151), daIs er Gefsners Tod Abels dort gelesen habe:

Abel was one of the first books my German master read to me. 
Aber diese schullektüre hat ihm fürs praktische leben gar nichts genützt. Er erklärt später wiederholt, daIs er kein Deutsch könne, 1) und er hat vor dem Deutschen offenbar ein ebenso stilles grauen gehabt, wie der Deutsche es gemeinhin vor dem Russischen als einer unaussprechbaren sprache empfindet. Deutsche orte, deren namen er nicht behielt, waren ihm Scrawsenhawsen oder Schrausenhaussen. ${ }^{2}$ ) Bei gelegenheit der feste im sommer 1814 wurde er einer prinzessin von Biron vorgestellt, Duchess of Hohen - God-knows-what; ähnlich sagt er, von einer gesellschaft bei frau von Staël, dals dort ein Prince of - gewesen sei;

I forget the name, - but it was of fifty consonants, - German of course. ${ }^{3}$ )

Als er einmal den ort Laibach erwähnt, fügt er hinzu:

or whatever the eructation of the sound may syllable into human pronunciation (L. J., V., s. 184).

In Don Juan (VIII, 49) sagt er :

And that but Blucher, Bulow, Gneisenan,

And God knows who besides in "an" and "ow",

Had not come up in time; usw.

Den namen Grillparzer nennt er ( $L$. J., V, s. 171)

a devil of a name, to be sure, for posterity; but they must learn to pronounce it.

Goethes namen dagegen, den er, nach Brandls vermutung ${ }^{4}$ ) "Goëthë" ausgesprochen hat, klang ihm angenehmer. ${ }^{5}$ )

Seinen in Deutschland sich mehr und mehr ausbreitenden ruhm vermochte er nur unvollkommen zu verfolgen. Er war ganz auf zufällige mitteilungen darüber angewiesen und konnte deutsche zeitungen, die ihm gesandt wurden, ohne übersetzung nicht verstehen ( $L . J .$, V, s. $33 ; 98)$. Man darf vermuten, daIs dies sehr bald anders gekommen wäre, wenn er sich länger in deutschem sprachgebiet aufgehalten hätte, als es der fall war. Auf seiner kurzen reise rheinaufwärts und auf seiner dreizehntägigen rundtour in der Schweiz, ins Berner Oberland III. 8.25.

1) L. J., III. s. 362. - L. J., V. 8. 37; 96 ; 334.

2) L. J., II. s. 246; VI. s. 36.

3) L. J., III. s. 98 und 371. Prinz v. Mecklenburg? Vgl. Hobhouse,

4) Ö. R., 8. 62 .

s) Vgl. Widmung des Marino Faliero. 
mit seinem "schlechten Deutsch" ( $L$. J., III, s. 356), hat er nichts weiter gelernt als sehr derbe verwünschungen, die er aus der kutschersprache und bei einem streit zwischen offizieren aufgelesen hatte (L.J., V, s. 172):

I can swear in German potently, when I like: Sacrament - Verfluchter - Hundsfott - and so forth; but I have little of their less energetic conversation.

Sad dogs! nennt er die Deutschen im Don Juan (X, 71), whom 'Hundsfott' or 'Verflucter'

Affect no more than lightning a conductor.

Grofse schwierigkeiten machten ihm deutsche ortsbezeichnungen. Aber es ist interessant, wie schon hier sich fortschritte aufweisen lassen. In seinem schweizer tagebuch (1816) führt er an:

Kletsgerberg $\left.{ }^{1}\right)$, "the Hockthorn, - nice names - so soft! -" Chateau de Schadau; Thoun; Neuhause; Interlachen (mehrfach); the Yung frau, i. e. Maiden (zweimal); the Wengen Mountain, der 1816 noch in ff. abarten erscheint: Wengen Alp; Wengeren Alp. Dent d'Argent [Silberhorn]; the little Giant (the Kleiner Eigher); and the great Giant (the Grosser Eigher); Wetterhorn. Dann: Jungfrau; Grindenwald (zweimal); Scheideck mountain. Rose Glacier [Rosenlauigletscher]. Reichenback waterfall. Oberhasli; Brientz; Bern; Fribourg; Jung-frau. Schreckhorn. Martinach [Martigny].

1817, in Italien, erwähnt er: Wengenalp; the Wengen; Wengrenalp; Wengeren; Wengeberg. Jungfrau (mehrfach); Lauterbrunnen. Grindelwald. Scheideck; Brientz; Reichenbach. Schreckhorn.

1820: the Staubach; Jungfrau.

Göttingen schrieb er 1811 (L.J., II, s. 4, anm.) richtig; 1821 anglisiert er es (L.J., V, s. 319) in Gottingen. Laibach ist ihm Leibach (L. J., V, s. 165) und Leybach (das., s. 184); Mollwitz: Molwitz (D. J., VIII, 22).

Im Manfred erwähnt er Mount Rosenberg, einen bergsturz; er meinte jedenfalls den Rossberg, der 1806 Goldau verschüttete.

1) Wiedergegeben nach Prothero, der von Moore's schreibung wiederholt abweicht. 
In Don Juan (X, $61 \mathrm{f}$.) spricht er von Berlin, Dresden, Manheim (Ausg. Paris 1835: Manhein), Bonn, Cologne.

Der sprachforscher Heine ist ihm Heyné (Waltz, 78). Koerner: Korner (L. J, VI, s. 294). Blücher: Blucher (mehrfach). Jakob Boehme: Jacob Behmen (L. J., II, s. 9; III, s. 239; IV, s. 238; D.J., VI, 2); doch ist dies die in England übliche form.

Goethe: meist Goethe (zum ersten mal: L. J., III, s. 371; so auch in den zueignungen); Goëthe: $L$. J., VI, s. 92; Poetry, V, s. 474, vorrede zu Def. Transf.). Einmal (L. J., V, s. 408) auch Göethe. Im versmals des Don Juan, XIII, 7, schreibt er Goethe. Hieraus schliefst Brandl offenbar, dafs er Goethe Goëthë gesprochen habe. Doch ist dies nicht sicher. Die form Goëthe tritt erst (vereinzelt) in Pisa auf, vielleicht unter dem einflufs Shelleys oder Medwins; dieser letzte schreibt stets Goëthe.

Württemberg: nach der damals üblichen schreibweise richtig: Wirtemberg (L.J., IV, s. 184).

Im Werner, den er 1815 begonnen hatte und 1822 vollendete, kommen folgende deutsche namen vor: Ulric (vgl. Byrons ersten dramatischen versuch, 1801: Ulric and Ilvina); Fritz; Henrick; Eric; Arnheim; Meister (anklang an Wilhelm Meister?); Rodolph; Ludwig; Josephine; Ida. Ferner I, 1. 259: Herman, Peter, Weilburg (vielleicht als vorname gedacht?), Conrad.

Im Manfred, dessen normännischen namen er aus dem Castle of Otranto von Walpole entlehnte (Brandl), kommt noch vor: Herman.

Ganz sporadisch finden wir belege, dals Byron sich wenigstens klar machte, was wenige deutsche worte besagten. So in dem wahlspruch:

$$
\text { "Ich Dien'" (Poetry VII, 8. 36), }
$$

und in Don Juan (XVI, 114), wo er anmerkt:

See the account of the ghost of the uncle of Prince Charles of Saxony, raised by Schroepfer - "Karl - Karl - was willst du mit mir?"

Im ganzen erging es aber Byron wie seinem Don Juan, von dem er (VIII. 57) sagt, er verstehe vom Deutschen soviel wie vom Sanskrit:

Short speeches pass between two men who speak No common language (das. 58). 
Es ist selbstverständlich, dafs er unter diesen umständen die deutschen dichter, die er lesen wollte, nur aus übersetzungen kennen lernen konnte (s. w. u.), und dafs er für den persönlichen verkehr mit Deutschen auf deren kenntnis anderer sprachen angewiesen war, wobei es bei Byron aber auch im mündlichen gebrauch des Französischen recht sehr haperte. So schreibt er einmal (L. J., III, s. 101):

Last night presentation to Princes Metternich, Radziwil und Czartoriski. You may suppose my horror, as I have no French. Luckily they speak Italian, which I once spoke fluently and have not quite forgotten.

So wenig deutsch er selbst konnte, so liefs er doch seinen spott an Sotheby wegen dessen übersetzung des Oberon von Wieland aus (L. J., IV, s. 151):

Have you had no new Babe of Literature sprung up .....?

No infant Sotheby, whose dauntless head

Translates, misunderstood, a deal of German ...

Und ein andermal (L.J., IV, s. 191):

No doubt he's a rare man

Without knowing German

Translating his way up Paruassus ....

Übrigens hat Wieland diese Oberon-übersetzung sehr freundlich aufgenommen. 1)

\section{Persönliche bekanntschaften.}

Byron ist, je weiter hin in seinem leben, desto häufiger mit Deutschen und auch deutschen Schweizern zusammengekommen.

Der erste Deutsche, den er erwähnt (L.J., I, s. 224), ist ein gewisser Friese, den er, in der absicht nach Persien zu reisen, als einen der dortigen verhältnisse kundigen auf empfehlung hin als diener übernahm. Er nennt ihn einen Ostpreufsen (L. J. I, s. 226). Wo dieser geblieben ist, wissen wir nicht. ${ }^{2}$ ) Byron gab den persischen plan erst in Konstantinopel auf; aber er spricht im Orient stets nur noch von Fletcher, nachdem er zwei andere diener, Murray und Rushton,

1) Vgl. Nat. Biogr., Sotheby.

2) Vgl. L. J., VI. s. 443: "I have sent back all my English servants but one" (Fletcher). 
von Gibraltar aus wieder nach hause gesandt hatte. Im verkehr mit gebildeten Deutschen sehen wir ihn zum ersten male in Athen (1810). Er sagt, er stehe gut mit fünf Teutonen und Cimbern, Dänen und Deutschen, die für eine akademie reisten (L.J., I, s. 307). Es waren künstler, archäologen und architekten. Einen davon, einen braunschweiger maler, Karl Wilhelm Gropius, nennt Byron einen Preufsen; er erzählt von ihm folgendes 1 ):

We had such ink-shed, and wine-shed, which almost ended in bloodshed! Lord E.'s "prig" ... quarrelled with another, Gropius by name (a very good name too for his business), and muttered something about satisfaction, in a verbal answer to a note of the poor Prussian: this was stated at table to Gropius, who langhed, but could eat no dinner afterwards. The rivals were not reconciled when I left Greece. I have reason to remember their squabble, for they wanted to make me their arbitrator.

Ein anderer Deutscher, der sich damals in Athen aufhielt, war der baierische architekt baron von Haller. Wahrscheinlich ist dieser unter a famous Bavarian artist $\mathrm{zu}$ verstehen (L.J., I, s. 309), den Byron ein andermal einen very superior German artist nennt. Er machte für Byron einige skizzen, die dieser jedoch in England später vergeblich erwartete.

In einer note (D. I) zu Childe Harold II, sagt Byron über die zahlreichen fremden, die damals in Athen lebten, "Franzosen, Italiener, Deutsche ....", dals sie über den charakter der Griechen nur einer meinung seien, obwohl sie sonst über alle anderen dinge mit grofser schärfe disputierten.

In short, all the Franks [Franzosen] who are fixtures, and most of the Englishmen, Germans, Danes, etc. of passage, came over by degrees to their opinion, on much the same grounds that a Turk in England would condemn the nation by wholesale, because he was wronged by his lacquey, and overcharged by his washerwoman.

Bei den Londoner siegesfesten 1814 lernte er die schon genannten hochstehenden persönlichkeiten kennen, und sah auch Blücher, den er an dieser stelle allein erwähnt, während er die anderen mit etc. etc. abtut ( $L . J$., III, s. 98) und nur gelegentlich ein andermal berichtet, dafs er auch den prinzen Paul von Württemberg sah (L.J., IV, s. 184). Einige monate

1) Note zu Ch. H., II. (Poetry, II, s. 170 ff.). 
später (L.J., III, s. 137) brachte ein Sir W. Knighton den phrenologen Spurzheim, der damals auf einer vortragsreise in England war, zu Byron,

a discoverer of faculties and dispositions from the head, wie Byron ihn nennt. 1)

I own, he has a little astonished me.

In der Schweiz, wohin er einen Schweizer, Berger, als diener mitnahm, ${ }^{2}$ ) freute sich Byron sehr darüber, den freund und begleiter des dichters Th. Gray, den Berner K. V. von Bonstetten kennen zu lernen, der zu dem kreise der Staël in Coppet gehörte. Byron lieh ihm eine übertetzung der briefe von Gray (L. J., III, s. 340 f.). ${ }^{3}$ )

Bonstetten himself is a fine and very lively old man, and much esteemed by his patriots; he is also a littérateur of good repute, and all his friends have a mania of addressing to him volumes of letters ..... He is a good deal at Coppet, where I have met him a few times.

Er schickte an Rogers dann das faksimile eines briefes von Bonstetten, da er meinte, die handschrift von Grays korrespondenten werde ihn interessieren. ${ }^{4}$ )

Vor allem aber lernte Byron hier August Wilhelm von Schlegel kennen. ${ }^{5}$ ) Er erwähnt ihn zum ersten male in dem selben briefe an Rogers:

Schlegel is in high force.

An die Staël schreibt er (L.J., III, s. 343):

I received the works of Mr. Schlegel, which I presume is the book to which you allude, and will take great care of it.

Wahrscheinlich (L.J., III, s. 343, anm. 3) handelt es sich

1) Byron spielt auf die kraniologie auch in D.J., XII. 22 an.

2) Moore, s. 284 . L. J., III. s. 350.

s) H obhouse sagt (II. s. 15): "Bonstetten has lent Gray's letters to Lord Byron" (originale?).

4) L. J., III. s. 343 . Das., IV. s. 95 (über die berühmtheit von Me de Staëls "Considérations sur la Révolution Française"): "Bonstetten told me in Switzerland it was very great." Vgl. auch L. J., IV. s. 297, anm.1.

5) Nicht "Fr. Schlegel", wie Kraeger, s. 60, sagt. Koeppel erwähnt die beziehungen Byrons zu A. W. Schlegel gar nicht; Ackermann sagt nur, dais B. in Coppet (1816) die bekanntschaft A. W. Schlegels machte (s. 76).

Anglia, N. F. XXIV. 
um die Vorlesungen über dramatische Kunst und Literatur, die 1808 deutsch, 1815 englisch erschienen waren.

Später $(1821 ;$ L. J., V, s. 334) erzählt er von A. W. Schlegel, dieser habe in einem gespräch mit Byron die verdienste Alfieris bestritten, den Byron aufs höchste schätzte; er sei auch zornig auf die Edinburgh Review gewesen, die nicht freundlich über Goethe geschrieben hatte. Byron fährt fort:

He went about saying, too, of the French - "I meditate a terrible vengeance against the French - I will prove that Molière is no poet".

Schlegel führte diese absicht dann in seinen vorlesungen aus (L. J., V, s. 334, anm.).

1817 verfafste Byron ein humoristisches gedicht (L.J., IV, s. 159 ff.), wo er nach dem bekenntnis fragt, in welchem die Staël gestorben sei.

I don't know that; - the fellow, Schlegel,

Was very likely to inveigle

A dying person in compunction

To try the extremity of Unction.

Weiterhin schrieb Byron an Murray (1821; L. J., V, s. 337):

They write from Paris that Schlegel is making a fierce book against ME: what can I have done to the literary Col-captain of late Madame? I, who am neither of his country nor his horde? Does this Hundsfott's intention appal you? if it does, say so. It don't me; for, if he is insolent, I will go to Paris and thank him. There is a distinction between native Criticism, because it belongs to the Nation to judge and pronounce on natives; but what bave $I$ to do with Germany or Germans, neither my subjects nor my language having anything in common with that Country? He took a dislike to me, because I refused to flatter him in Switzerland, though Madame de Broglie begged me to do so, "because he is 80 fond of it. Voilì les hommes."

Drei tage später (das., s. 339 f.):

If I do not err, I mentioned to you that I had heard from Paris, that Schlegel announces a meditated abuse of me in a criticism. The disloyalty of such a proceeding towards a foreigner, who has uniformly spoken so well of Mo de Staël in his writings, and who, moreover, has nothing to do with continental literature or Schlegel's country and countrymen, is such, that I feel a strong inclination to bring the matter to a personal arbitrament, provided it can be done without being ridiculous or unfair. His intention, howerer, must be first fully ascertained; before I can 
proceed; and I have written for some information on the subject to Mr. Moore. The Man was also my personal acquaintance; and though I refused to flatter him grossly (as $\mathrm{Me}^{\mathrm{e}} \mathrm{de} \mathrm{B}$. requested me to do), yet I uniformly treated him with respect - with much more, indeed, than any one else: for his peculiarities are such, that they, one and all, laughed at him; and especially the Abbe Chevalier di Breme, who did nothing but make me laugh at him so much behind his back, that nothing but the politeness, on which I pique myself in society, could have prevented me from doing so to his face. He is just such a character as William the testy in Irving's New York. But I must have him ont for all that, since his proceedings (supposing it to be true), is ungentlemanly in all its bearings - at least in my opinion, but perhaps my partiality misleads me.

It appears to me that there is a distinction between native and foreign criticism in the case of living anthors, or at least should be; I don't speak of Journalists (who are the same all over the world), but where a man, with his name at length, sits down to an elaborate attempt to defame a foreigner of his acquaintance, without provocation and without legitimate object: for what can I import to the Germans? What effect can I have upon their literature? Do you think me in the wrong? if so, say 80.

Dafs Byron an Moore in dieser sache schrieb, geht aus seiner frage hervor (das., s. 378):

You have not answered me about Schlegel - why not?

Moore vermied es vielleicht, darauf einzugehen; denn obwolll Byron ihm zuvor geschrieben hatte (das., s. 333):

I know Schlegel well - that is to say, I have met him occasionally at Coppet, -

so war Moores eindruck von Schlegels empfindungen gegen Byron nicht der günstigste, und er mochte weiterungen befürchten :

[Schlegel] ... is evidently not well inclined towards Lord Byron; thinks he will outlive himself, and got out of date long before he dies. Asked me if I thought a regular critique of all Lord B.'s works, and the system on which they are written, would succeed in England, and seems inclined to undertake it. (Moore's Tagebuch, zit. L. J. V., s. 333, anm.)

Noch eine aufzeichnung Byrons über Schlegel (das., s. 429) mag hier platz finden:

Somebody asked Schlegel (the Dousterswivel of Madame de Staël) "whether he did not think Canova a great Sculptor?" "Ah!" 
replied the modest Prussian, "did you ever see my bust by Tiecke?" ")

Den weg, den Byron zu seinem abstecher ins Oberland und nach Freiburg i. Ü. wählte, verdankte er den angaben eines Deutschen $(L . J .$, IV, s. 96). In Brienz kamen vier landmädchen aus Oberhasli ins gasthaus und sangen ländliche weisen, die Byron ebenso schön fand wie ihre stimmen.2) Auf der rückreise gab ihm ein mädchen in Interlaken blumen und sprach mit ihm; aber er verstand nichts davon (L.J., III, s. 362):

I do not know whether the speech was pretty, but as the woman was, I hope so.

In Oberitalien kam Byron natürlich auch mit den Österreichern, den herren des landes, in berührung. Gleich in Mailand geriet der von ihm entlassene, wenig sympathische arzt, Dr. Polidori, im Skalatheater in einen heftigen zwist mit einem österreichischen offizier. Baron Stendhal (Henri Bayle) berichtet darüber ${ }^{3}$ ):

One evening ... Silvio Pellico ... came in breathless haste to apprize Lord Byron, that his friend and physician, Polidori, had been arrested. We instantly ran to the guard-house. It turned out that Polidori had fancied himself incommoded in the pit by the fur cap of the officer on guard, and had requested him to take it off, alleging that it impeded his view of the stage. The poet Monti had accompanied us, and, to the number of fifteen or twenty, we surrounded the prisoner. Every one spoke at once; Polidori was beside hinself with passion, and his face red as a burning coal. Byron, though he too was in a violent rage, was, on the contrary, pale as ashes. His patrician blood boiled as he reflected on the slight cousideration in which he was held .... At all events, the Austrian officer spied the leaven of sedition in our countenances, and .... probably thought of the insurrection of Genoa, in 1740. He ran from the guard-house to call his men ... Monti's idea was excellent: "Sortiamo tutti; restino solamente $i$ titolati!" De Brême remained, with the Marquis de

1) Gemeint ist Christian Friedrich Tieck, der bruder Ludwig Tiecks, der bekannte bildhauer, der $\mathbf{z}$. b. die Goethebüste in der Walhalla fertigte und obenso eine der Me de Staël und (1809 in Coppet) die von A. W. von Schlegel. Vgl. Hob ho a se, II. s. 43 and Allg. D. Biogr. XXXVIII, s. 249.

2) L. J., III, s. 361. Aus Yverdun berichtet er (cf. L. J., III, s. 363): "the Auberge nearly full - a German - with princess and suite".

3) L. J., III, s. 441 f. Karz auch Byron selbst, das., s. 383. Vgl. Polidori, s. $186 \mathrm{ff}$. 
Sartirana ..., Count Confalonieri, and Lord Byron. The gentlemen having written their names and titles, the list was handed to the officer on guard, who instantly forgot the insult offered to his fur cap, and allowed Polidori to leave the guard-house. In the evening, however, the doctor received an order to quit Milan within twenty-four hours.

In Venedig verkehrte er öfters im kreise des statthalters grafen Goetz. Er hebt hervor, dals dessen gattin eine sehr liebenswürdige und angenehme frau mit beachtenswert guten manieren sei. ${ }^{1)}$ Von der gesellschaft selbst sagt er, sie sei die beste; im übrigen sei es dort so, wie bei allen solchen herdenartigen meetings; es sei da eine bunte schar von Österreichern, Deutschen, vornehmen Venezianern. Auf die dauer gefiel es Byron nicht dort; es waren ihm die frauen zu einfach; die förmlichkeit der gesellschaft langweilte ihn.

Das nächste, was Byron von Deutschen berichtet, ist seine humoristische schilderung der jungen künstler, die er in Rom sah. Er schreibt an Murray (L.J., IV, s. 118):

It may perhaps interest you to hear that a set of German artists here allow their hair to grow, and trim it into his [Raffael's] fashion, thereby drinking the cummin ${ }^{2}$ ) of the disciples of the old philosopher; if they would cut their hair, convert it into brushes, and paint like him, it would be more "German to the matter". ${ }^{8}$ )

Zwei jahre später hören wir von einer unangenehmen störung, die eine deutsche dame ihm bereitete: es bandelte sich um eine liebelei mit einer vornelmen jungen Venezianerin namens Angelina, die Byron manches stelldichein gewährte. Er schreibt darüber u. a. an Murray (L. J., IV, s. 302):

I hare undergone some trouble on her account, for last winter the truculent tyrant her flinty-hearted father, having been informed by an infernal German, Countess Vorsperg (their next neighbour), of our meetings, they sent a priest to me, and a Commissary of police, and they locked the Girl up ....

Bald darauf verwickelte ihn in Bologna, nach seiner ersten reise nach Ravenna, ein deutscher offizier in einen pferdehandel.

') L.J., IV, s. 25. - Vgl. auch das., s. 13; 26; 86; 208. Im brief an Hoppner (L. J., IV, s. 189) nennt er ihn "Count Goess".

2) Vgl. L. J., IV, s. 118, anm. 2.

8) "German to the matter" ist ein zitat, welches bedeutet: es wäre zweckmäfsig, und das Byron öfters anwendet, z. b. L. J., IV, s. 65 . 
Auch hierüber schüttete er seinem vertrauten Murray das herz aus ( $L . J .$, IV, s. 350 ff.):

I have been in a rage these two days, and am still bilious therefrom. You shall hear. A Captain of Dragoons, Ostheid, Hanoverian by birth, in the Papal troops at present, whom I had obliged by a loan when nobody would lend him a Paul, recommended a horse to me, on sale by a Lientenant Rossi .... I bought it. The next day, on shoeing the horse, we discovered the thrush, - the animal being warranted sound. I sent to reclaim the contract and the money. .... What could I do? ... His friend Ostheid is at Forli; we shall meet on my way back to Ravenna, The Hanoverian seems the greater rogue of the two; and if my valour does not ooze away like Acres's - "Odd flints and triggers!" if it should be a rainy morning, and my stomach in disorder, there may be something for the obituary.

Byron ging aber zunächst nicht nach Ravenna zurück, sondern wieder nach Venedig, und wir hören nichts mehr von Ostheid.

Weitere unannehmlichkeiten zog sich Byron selbst zu, durch seine den Österreichern gegenüber höchst feindselige haltung beim aufstande der Carbonari von 1821-221). Byron stand mit ganzem herzen auf seiten der Italiener, deren freiheit ihm als the very poetry of politics (L.J., V, s. 205) erschien. Schliefslich beklagte er sich, dals die Österreicher ihn seit fünf jahren in der Mailänder zeitung in jeder art mifshandelt hätten; ja, er behauptete, man habe einen mörder gegen íhn gedungen, da man ihn für die seele des aufstandes hielt, und dies komme auf rechnung der "deutschen barbaren" (L. J., V, s. 297).

Die beziehungen Byrons zu einem offenbar im dienst des grolsherzogs von Toskana stehenden baron von Lützerode, der den Cain übersetzte, sind nicht ganz klar.

Zunächst berichtet Medwin (II, s. 82 f.) folgendes gespräch mit Byron:

B.: "You tell me that the Baron Lutzerode has been asking you for some authentic particulars of my life, to affix to his translation of 'Cain', and thus contradict the German stories circulated about me, and which, I understand, even Goëthe believes. Why don't you write something for him, Medwin? ...."

I said "My friend the Baron is a great enthusiast about you and I am sure you would like him."

1) Näheres hierüber s. u. s. 342 ff. 
Byron erzählt dann a noble trait von dem baron, wovon Taaffe ihm berichtete. Da sagte Medwin:

"Well then, shall I bring the Baron?"

"I have declined", replied Lord Byron, "going to Court; and as he belongs to it, must also decline his visit ... I will make my peace with your amiable friend by sending him a 'Cain' and 'Don Juan' as a present, and adding to the first page of the latter an impression of $\mathrm{my}$ seal with the motto 'Elle vous suit partout'.1) This will please a German sentimentalist."

Ob Byron seine absicht ausführte, wissen wir nicht; aber es ist möglich, dals sich folgende bemerkung (L.J., VI, s. 74) auf ein antwortschreiben Lützerodes bezieht:

Goethe and the Germans are particularly fond of Don Juan ... I had heard something like this before through Baron Lutzerode.

Auch die bekanntschaft des prinzen Clemens von Sachsen (1798-1822) lehnte er ab, als dieser ihn in Pisa kennen zu lernen wünschte. Dieser prinz war ein grolser verehrer Byrons und setzte jedem kapitel seines tagebuches eine strophe aus Childe Harold als motto vor. $\left.{ }^{2}\right)$ Er war ein bruder der grofsherzogin von Toskana und starb anfang 1822 in Florenz.

Am eingehendsten hatte sich Byron persönlich mit Deutschen und deutschen Schweizern infolge seiner tätigkeit für und in Griechenland zu befassen.

Am 12. Mai 1823 (L. J., VI, s. 210) schrieb er aus Genua: that many foreign officers, Italian, French, and even Germans (but fewer of the latter), have returned in disgust ...

Einige tage später (L. J., VI, s. 214 ff.; 21. Mai 1823) konnte er folgendes berichten:

Yesterlay I fell in with two young Germans, survivors of general Normann's band. They arrived at Genoa in the most deplorable state - without food - without a son - without shoes. The Austrians had sent them out of their territory on their landing at Trieste; and they had been forced to come down to Florence, and had travelled from Leghorn here, with four Tuscan livres (about three francs) in their pockets. I have given them twenty Genoese scudi (about a hundred and thirty-three livres, French money)

1) Vgl. Don Juan, I, 198 .

2) Vgl. Hobhouse, III, s. 7. Er nennt ihn "the Duke of Saxe -". Vgl. aber Williams, E. E., Journal, ed. R. Garnett, 1902, s. 32, und Cohn, Stammtafeln, tafel 70 . 
and new shoes, which will enable them to get to Switzerland, where they say they have friends. ... I tried their veracity, 1st by their passports, and papers; 2dly, by topography, crossquestioning them ...; and 3dly, in Romaic, of which I found one of them, at least, knew more than $I$ do. One of them (they are both of good families) is a fine handsome young fellow of threeand-twenty - a Wirtembergher, and has a look of Sandt about him - the other a Bavarian, older and flat-faced, and less ideal, but a great, sturdy, soldier-like personage. The Wirtembergher was in action at Arta ... These two left Greece by the direction of the Greeks ... they wandered from island to island, and got from Milo to Smyrna, where the French consul gave them a passport, and a charitable captain a passage to Ancona, whence they got to Trieste ...

Adolphe (the younger) commanded at Navarino for a short time; the other, a more material person, ... seems chiefly to lament of a fast of three days at Argos, and at the loss of twentyfive paras a day of pay in arrear, and some baggage at Tripolitza; but takes his wounds, and marches, and battles in very good part. Both are very simple, full of naïveté, and quite unpretending ....

When these lads saw two Piedmontese regiments yesterday, they said: "Ah! if we had but these two, we should have cleared the Morea" .... They seem to lay great stress upon a few regular troops, say that the Greeks have arms and powder in plenty ... [usw.]. Altogether it would be difficult to show more practical philosophy than this remnant of our "puir hill folk" have done; they do not seem the least cast down, and their way of presenting themselves was as simple and natural as could be. They said, a Dane here had told them that an Englishman, friendly to the Greek cause, was here; and that, as they were reduced to beg their way home, they thought they might as well begin with me.

P.S. I have, since I wrote this, seen them again. Count P. Gamba asked them to breakfast. One of them means to publish his Journal of the campaign. The Bavarian wonders a little that the Greeks are not quite the same with them of the time of Themistocles ... and at the difficulty of disciplining them; but he is a bon homme, and a tactitian ... the other seems to wonder at nothing.

Graf Gamba berichtet (Kennedy, s. 405 f.), dals Byron und er die beiden auf einem ritt zwei meilen von Genua entfernt antrafen, nel più desolato stato.

In loro portamento era nobile, e fiero, e la loro fisonomia li indicava nativi di Germania: due giorni appresso comparvero per caso chiedendo limosina a Milord, alla sua abizione .... 
volevano tornare alla loro patria, in Virtembergh; e così avevano mendicato la loro vita da Ancona ... Mylord li forni di ogni mezzo per potersi recare fino alla patria loro.

Diese hübsche episode wirft ein deutliches licht auf das tiefe interesse, das Byron der griechischen sache entgegenbrachte. ${ }^{1)}$

In Griechenland boten sich Byron zehn Deutsche als leibwache an, die schon zwei jahre in Griechenland gedient hatten. ${ }^{2}$ ) Dann stiels vor allem ein junger Schweizer Arzt, Julius Millingen (geb. 1800) zu Byron, an den er empfohlen war. Er erreichte den lord $\mathrm{zu}$ anfang November 1823 in Kephalonia. Er war einer der ärzte, die ihn während seiner letzten krankheit pflegten. In Millingens armen ist, wie dieser sagt, ${ }^{3}$ ) Byron gestorben. Er hat memoiren herausgegeben, die eine wichtige quelle für die Byron-episode des griechischen freiheitskampfes sind. Er genols offenbar Byrons vertrauen. ${ }^{4}$ Dieser beantragte für ihn beim komitee das gleiche gehalt, wie es ein anderer arzt, dr. Tindall, erhielt, da sein dienst wahrscheinlich schwerer sein werde (L. J., VI, s. 280). Weniger angenehm war ihm ein anderer Schweizer, ein dr. Johann Jakob Meyer. Er war von colonel Stanhope, dem bevollmächtigten des englischen Griechenkomitees, mit der herausgabe seiner Griechischen Chronik, die 1824 erscheinen sollte, betraut. Er machte Byron durch sein draufgängerisches wesen $\mathrm{zu}$ schaffen. Zuerst wollte Byron ihm die alleinige redaktion entziehen; dann mufste er die ganze auflage einer nummer vernichten lassen, weil ein so heftiger ausfall gegen die österreichische regierung darin war, dafs es selbst Byron zu arg erschien (Kennedy, s. 300). Byron mochte ihn auch deshalb nicht, weil er einerseits demokratisch gesinnt, andererseits in lächerlicher weise titelsüchtig, und überdies zu vertraulich war. ${ }^{5}$ ) Kurz vor seinem tode schrieb Byron über ihn (L. J., VI, s. 355):

Dr. Meyer, the Editor, with his unrestrained freedom of the press, and who has the freedom to exercise an unlimited discretion,

1) Wer die beiden waren, konnte ich aus der philhellenischen literatur nicht feststellen.

2) G a mba, a.a.o. s. 153 .

3) Hobhouse, III, s. 64 .

4) Elze, s. 317 .

5) L. J., VI, s. 355, anm. 1 . 
- not allowing any articles but his own and those like them to appear, - and in declaiming against restrictions, cuts, carves, and restricts (as they tell me) at his own will and pleasure .... Of all petty tyrants, he is one of the pettiest, as are most demagogues, that ever I knew.

Auch sonst hatte Byron viele schwierigkeiten zu bestehen, und es waren nicht zum wenigsten Deutsche, die sie bereiteten. Er schreibt (L. J., VI, s. 318):

Between Suliote chiefs, German barons, English volunteers, and adventurers of all nations, we are likely to form as goodly an allied army as ever quarrelled beneath the same banner.

Und ain 26. 3. 24 (L. J., VI, s. 361):

There is a dissension among the Germans about the conduct of their Committee, and an examination amongst themselves instituted. What the result may be cannot be anticipated, except that it will end in a row, of course, as usual. ${ }^{1}$ ) The English are all very amicable as far as $I$ know ... and we have no quarrels with the other foreigners.

Bei der organisation der truppen weigerte sich ein preufsischer offizier, Kindermann, unter Parry, der ihm im rang nicht gleichstand, zu dienen. Er kam zu Byron, um sich des ihm zugeteilten postens wieder zu entledigen. Gamba (s. 158) berichtet weiter darüber:

L. B. did all he could to dissuade him, and he joked him not a little on the quarterings of his German escutcheon, and on the folly of introducing his prejudices into a country like Greece. "As for myself", said B., "I should be perfectly ready to serve as a common soldier, under any body, if it be thought of any good to the cause." Mr. K., however, was not to be persuaded, and withdrew from us; but all the other Germans remained.

Am 29. März 1824 mufste ein kriegsgericht über einen dieb abgehalten werden (L. J., VI, s. 364 f.):

The German officers wanted to flog, but I positively prohibited anything of the kind: the culprit was dismissed the service publicly, and conducted through the town to the Police Office to have him punished according to the Civil law.

Graf Gamba sagt darüber ${ }^{2}$ ):

1) Vgl. über solche "ärgerliche szenen" A. Müll er, Erinnerungen an Griechenland v. J. 1822, Zürich, 1897. Auch sonst wird übereinstimmend von dergleichen berichtet.

2) L. J., V, s. 365, anm. 1. Vgl. auch ferner das., s. 369. 
Byron declared that, as far as he was concerned, no barbarous usages, however adopted even by some civilized people, should be introduced into Greece ...1) We hit upon an expedient which favoured our military discipline: but it required not only all Lord Byron's eloquence, but his authority, to prevail upon the Germans to accede to it. The culprit had his uniform stripped off his back, in presence of his comrades ... [usw.]. This example of severity, tempered by a humane spirit, produced the best effect upon our soldiers ....

Drei tage später hatte er es wieder mit einem Deutschen zu tun. Um mitternacht des 31. März erflehte ein Grieche aus Missolonghi Byrons schutz gegen einen preufsischen offizier, $\left.{ }^{2}\right)$ der bei ihm im quartier lag. Er kam, wie Gamba erzählt, betrunken heim, brach die türe auf, zog seinen säbel und erschreckte die familie. Byron schickte einen offizier und einen zug soldaten hin und liefs den ruhestörer arretieren, der sich über die zeit wo, und die art wie dies stattfand beschwerte. Darauf erwiderte Byron (L. J., VI, s. 367 f.):

Sir, - I have the honour to reply to your letter of this day. In consequence of an urgent, and, to all appearance well-founded complaint, made to me yesterday evening, I gave orders to Mr. Hesketh to proceed to your quarters with the soldiers of his guard, and to remove you from your house to the Seraglio; because the owner of your house declared himself and his family to be in immediate danger from your conduct; and added, that that was not the first time you had placed them in similar circumstances. Neither Mr. Hesketh nor myself could imagine that you were in bed, as we had been assured of the contrary; and certainly such a situation was not contemplated. But Mr. Hesketh had positive orders to conduct you from your quarters to those of the artillery brigade; at the same time being desired to use no violence; nor does it appear that any was had recourse to. This measure was adopted because your landlord assured me, when I proposed to put off the inquiry until the next day, that he could not return to this house without a guard for his protection, and

1) Byron hätte den anfang mit entriisteten vorstellungen gegen solche "barbarous usages" beim britischen statthalter der Jonischen inseln machen können. In einem mir freundlich zur verfügung gestellten manuskript, v. Sailer, Dietrich, Tagebuch-Aufzeichnungen eines P'hilhellenen, 1821-22, heifst es (s. 43): "eigentlich sei es jedem schiffer und Zantioten bei 25 stockstreich verboten, jemand von diesem lande mit [fort] zu nehmen".

2) So sagt Byron, L. J., VI, s. 369 . Gamba nennt ihn irrig einen Russen (L. J., VI, s. 367, anm. 1). 
that he had left his wife and daughter, and family, in the greatest alarm; on that account putting them under our immediate protection; the case admitted of no delay. As I am not aware that $\mathrm{Mr}$. Hesketh exceeded his orders, I cannot take any measures to punish him; but I have no objection to examine minutely into his conduct. You ought to recollect that entering into the auxiliary Greek corps, now under my orders, at your own sole request and positive desire, you incurred the obligation of obeying the laws of the country, as well as those of the service.

Byron berichtet weiter (L. J., VI, s. 369 f.):

This, it appears, did not please the German Confederation '): but I stuck by my intent, and have given them plainly to understand, that those who do not choose to be amenable to the laws of the country and service, may retire; but that in all that $I$ have to do, I will see them obeyed by Foreigners or Natives.

Mehr klarheit und stärke des willens, als Byron sie in diesen letzten monaten seines lebens unter besonders schwierigen verhältnissen an den tag legte, kann man nicht verlangen. Aber diese ruhe und energie war ihm hier grundsatz. Am 11. März (L. J., VI, s. 350) sprach er es aus, wie grofs er über seine pflicht Griechenland gegenüber dachte:

In questi affari io non ho ne mire personali ne odii particolari, ma il sincero desiderio di meritare il nome di amico di vostra patria e patrioti.

Um so gewichtiger ist sein lob der deutschen Philhellenen (L. J., VI, s. 293 f.):

I can assure you that Colonel Napier and myself are as decided for the cause as any German student of them all.

So finden wir denn auch kein bitteres wort über die hitzigen Deutschen, die ihm - wenn sie es auch nicht allein waren, die ihm verdriefslichkeiten bereiteten, - doch so viel zu schaffen machten. Im gegenteil; Byron schätzte ihre tätigkeit und den im allgemeinen unter ihnen herrschenden geist, und zwar besonders diesen. Durch colonel Stanhope hatte er unmittelbar über die organisation der deutschen Griechenkomitees gehört; denn dieser hatte sie, wie Byron sagt, sämtlich aufgesucht, als er von England nach Griechenland reiste (L. J., VI, s. 279).

1) Damit sind die Deutschen in Missolonghi gemeint. Denn Byron schrieb dies schon "some days" nach dem kriegsgericht vom 29. März. 
Auch verschönten die Deutschen Byron hie und da den abend mit ihrer musik, die er stets besonders liebte (Gamba, s. 118). -

In einem kleinen artikel über "den gegenwärtigen zustand von Griechenland"1) äufsert er sich zusammenfassend:

One thing is essential to remark, viz. that hitherto no stranger has succeeded in Greece either in doing much for the natives, or for himself. French, Germans, Italians, English, Poles, - men of all nations, ages, and conditions, - military and naval, rich and poor, good and evil, speculative and practical, - merchants, officers, tars, generals, German Barons and Bankers, English gentlemen and adventurers, - and surely some men of talent and good intention among them - have in the course of the last three years run the Gauntlet of Greece, and, of the Survivors of fever, famine, fatigue, and the sword, the greater part of those who have not gone back in disgust - remain in misery. -

Soviel unangenehmes Byron also, von Schlegel, vom dragonerhauptmann Ostheid und der lauernden nachbarin der hübschen Angelina, der gräfin Vorsperg, bis zu dem den frieden des griechischen hauses störenden offizier von Deutschen begegnet ist, so hat er doch in ihnen bereitwillige und begeisterte mithelfer an seinem letzten idealen werke erkannit und geachtet.

\section{Urteile über deutsche art, die deutsche Schweiz und die österreicher.}

Auch sonst schätzte Byron manches Deutsche, oder hat sich urteile darüber gebildet. Er sagt einmal (L.J., V, s. 68), dals, während der mut der Franzosen der eitelkeit entstamme, der der Deutschen sich aus dem phlegma ableite. Ferner betont er (das., s. 172), dals er alles gern möge, was er von ihren schriften gelesen, und alles, was er von ihrem land und volk gesehen habe.

Den deutschen frauen macht er, der frauenverspotter, ein sehr beachtenswertes kompliment; dort, wo er von den hervorragend guten manieren der gräfin Goetz spricht $(L . J .$, IV, s. 25), manieren: as many of the German women have. Und

1) 26. 2. 24. L. J., VI, s. 441. 
ein andermal (L.J., V, s. 172): I like, however, their women. $\left.{ }^{1}\right)$ - Eine davon taucht im gleichen zusammenhang in dem kranz der frauen auf, die seine neigung besalsen; leider völlig unbestimmt: eine Constance, in die er, wie er versichert, einmal "so verzweifelt" verliebt war. Weiteres ist darüber nicht bekannt. - Auch Schweizerinnen hatten ihm mehrfach unmittelbar gefallen.

Aus dem III. gesang von Childe Harold, sowie aus Polidoris tagebuch geht hervor, dals die behagliche stimmung, die über der Rheingegend liegt, der ländliche charakter des von ihnen durchreisten gebietes, die ordnung und der sorgfältige anbau des ackergrundes ihnen aufserordentlich gefielen; ebenso aber auch die freundlichkeit der bewohner. Bei Polidori ist am Mittelrhein alles beautiful und sublime oder splendid. Am Oberrhein ist alles fine.

Ein umstand freilich blieb Byron als des spottes wert zeitlebens in erinnerung: die langsamkeit und das fluchen der deutschen ${ }^{2}$ ) postillione. Sein mächtiger reisewagen sowie die für seine diener dazu gekaufte kalesche wurden mit geheuerten pferden bespannt, die öfters gewechselt wurden. Auch waren die strafsen nicht immer angenehm ${ }^{3}$ ), z. b. von Aachen nach Köln (Polidori, s. 76). Dies alles blieb für ihn ein gegenstand des spottes. Er verweilte auch in der verulkung der reise Sotheby's (L.J., IV, s. 452 f.) mit behagen dabei. Er sagt dort, die geduld der reisenden sei mit der Hiobs zu vergleichen gewesen, da sie sie praktisch auf einer mehrtägigen reise auf deutschen strafsen mit deutschen postillionen geübt hätten. Fr läIst Sotheby in einem wagen befördert werden, der, though large, was neither speedy nor convenient. It admitted the rain, but excluded the light, and was only airy during a high wind, or a snow storm. However, by dint of being obliged

1) Dies und einiges wenige andere hat $\mathrm{Pughe}$ in seiner arbeit Byron und Wordsworth (1902) in einer anmerkung (s. 37 f.) vermerkt. Von allen äufserungen Byrons über die Schweiz führt er nur die "nichts weniger als 8chmeichelhafte charakteristik" der Schweiz (L. J., V, s. 365; 8. u. 8. 339) an, die sich wohl nur auf Genf beziehen kann, da Byrons urteile über das Oberland völlig anders lauten. Diese fehlen bei Pughe.

2) und schweizerischen; vgl. Polidori, s. 92.

?) Manchmal aber auch vorzüglich; dann freilich von Napoleon angelegt; vgl. Polidori, s. 86. 
to get out on going up hill, and of being thrown out on going down one, they contrived to see 80 much of the Country as to acquire a tolerable notion of the landscape.

Hierher gehört es auch, wenn er (Werner, I, 1. $213 \mathrm{ff}$. ), wo er von Stralenheim spricht, sagt:

.. a great personage, who fain would cross

Against the stream and three postillions' wishes, Is drowned below the ford, with five posthorses, A monkey, and a mastiff, and a valet.

Freilich erfahren wir aus Polidoris tagebuch nichts von derartigen abenteuern.

Endlich verspottet Byron das deutsche postwesen in der lustigsten stanze, die er wohl je schrieb; dort, wo er die fahrt Don Juan's von der küste nach London schildert (X, 71):

On with the horses! Off to Canterbury!

Tramp, tramp o'er pebble, and splash, splash through puddle; ${ }^{1}$ )

Hurrah! how swiftly speeds the post so merry!

Not like slow Germany, wherein they muddle

Along the road, as if they went to bury

Their fare; and also pause besides, to fuddle

With " schnapps" - sad dogs! whom "Hundsfot", or "Verflucter", Affect no more than lightning a conductor. -

Auch D.J., X, 60 spielt er auf die langsamkeit der deutschen postillione an. -

Von den Deutschen als nationaltypen hat Byron offenbar nicht viel gutes gedacht. In seiner dandyzeit spricht er ziemlich verächtlich von ihnen. 1811 war er mit Webster in einen streit geraten; Byron wollte Webster nur einen neuen wagen, nicht aber die ausstattung desselben überlassen. Webster hatte ihm darüber einen sehr heftigen brief geschrieben; Byron aber schob die schuld versöhnlich einem dritten zu (L.J., II, s. 5):

Beware your Tutor, for I am sure he Germanized that sanguinary letter.

Und ein andermal (L. J., II, s. 4, anm.):

The best thing you can do for the Tutor you speak of will be to send him in your Vis (with the lining) to 'the U-Niversity of Göttingen'. How can you suppose (now that my own Bear

1) Vgl. Scott's übersetzung von Bürgers Lenore. 
is dead) that I have any situation for a German genius of this kind, till I get another, or some children?

Auch das wort Teutonic - ganz abgesehen von den schmückenden zugaben, die er für angemessen hält - , das ein paarmal in der Londoner zeit von ihm gebraucht wird, zeigt gerade keine hochachtung (L.J., II, s. 245 f.):

Madame de Staël-Holstein has lost one of her young Barons, $\left.{ }^{1}\right)$ who has been carbonadoed by a vile Teutonic adjutant, - kilt and killed in a coffeehouse at Scrawsenhawsen.

Ferner (L. J., II, s.. 326):

Last night, at Lord H.'s - I was trying to recollect a quotation (as $I$ think) of Stael's, from some Teutonic sophist abont architecture. "Architecture", says this Macoronico Tedescho, "reminds me of frozen music". It is somewhere - but where? - the demon of perplexity must know and won't tell. I asked M., and he said it was not in her: but Puységur said it must be hers, it was so like. H. laughed, as he does at all "De l'Allemagne" - in which, however, he goes a little too far.

Byron wiederholte diesen gedanken in einer anmerkung zu der bekannten stelle in The Bride of Abydos (I, 179): the Music breathing from her face:

Someone has said that the perfection of Architecture is frozen music - the perfection of Beauty to my mind always presented the idea of living Music.

Dies bezieht sich wohl auf Schelling, der die architektur mehrfach mit "erstarrter musik" verglich. ${ }^{2}$ )

Die schon von Shakespeare als deutsche nationaleigenheit behauptete trunksucht fand Byron nicht ohne behagen in Blücher verkörpert: Nach dem besuch von Chillon schrieb er in sein tagebuch (L.J., III, s. 353):

The Corporal who showed the wonders of Chillon was as drunk as Blucher, and (to my mind) as great a man.

Dals der besieger Napoleons in einem etwas schweren zustande von einem essen in Carlton House zu Lady Castlereagh

1) Ihr sohn Albert. Er fiel in einem duell in Doberan. Vgl. L. J., II, s. 246, anm. 1 .

2) Vgl. L. L. Mackall, Goethes "Edler Philosoph" (Euphorion, XI, 8. 103 ff.). Dieser vergleich wurde teils Goethe, teils F. Schlegel, teils (wohl nach Byron) Me de Staël selbst zugeschrieben. In De l'Allemagne selbst finde ich nichts davon. Vgl. übrigens Engl. Studien, XLIV, s. 473 f. 
gekommen war ${ }^{1}$ ), hatte in der englischen aristokratie jedenfalls grofsen Eindruck gemacht, Byron aber, dessen abgott Napoleon war, offenbar grimmiges vergnügen bereitet.

1821 schrieb er in seinen Detached Thoughts (L. J., V, s. 462) folgende späne nieder:

... the other [Wellington] is a mere Corporal, dividing with Prussians and Spaniards the luck which he never deserved. He even - but I hate the fool, and will be silent.

I remember seeing Blucher in the London Assemblies, and never saw anything of his age less venerable. With the voice and manners of a recruiting Sergeant, he pretended to the honours of a hero; just as if a stone could be worshipped, because a Man had stumbled over it. -

Als etwas wenig erfreuliches betrachtete Byron den dentschen walzer in der art, wie er in England getanzt wurde (L. J., III, s. 361). ${ }^{2}$ ) Bekanntlich widmete er ihm eine besondere dichtung, The Waltz. ${ }^{3}$ ) Darin heilst es (vers $29 \mathrm{ff}$.):

Imperial Waltz! imported from the Rhine

(Famed for the growth of pedigrees and wine),

Long be thine import from all duty free,

And Hock itself be less esteemed than thee;

In some few qualities alike - for Hock

Improves our cellar - thou our living stock.

The head to Hock belongs - thy subtler art

Intoxicates alone the heedless heart:

Through the full veins thy gentler poison swims,

And wakes to Wantonness the willing limbs.

Oh, Germany! how much to thee we owe,

As heaven-born Pitt can testify below,

Ere cursed Confederation made thee France's,

And only left us thy $d-d$ debts and dances!

Of subsidies and Hanover bereft,

We bless thee still - for George the Third is left!

Of Kings the best - and last, not least in worth,

For graciously begetting George the Fourth.

To Germany, and Highnesses serene,

Who owe us millions - don't we owe the Queen?")

1) L. J., III, s. 93. Aus dem Journal von Miss Berry.

2) Auch Hobhouse (I, s. 23) sagt von den leuten in Brienz, dais sie den walzer tanzten "in such a manner as might shame a ball-room in England".

3) Aufserdem spielt er darauf an D. J., XI. 69 und XII. 32.

4) Charlotte von Mecklenburg-Strelitz.

Anglia. N.F. XXIV. 
To Germany, what owe we not besides?

So oft bestowing Brunswickers and brides; Who paid for vulgar, with her royal blood, Drawn from the stem of each Teutonic stud:

Who sent us - so be pardoned all her faults A dozen dukes, some kings, a Queen - and Waltz.

But peace to her - her Emperor and Diet, Though now transferred to Buonaparte's "fiat!" Back to my theme - 0 muse of Motion! say, How first to Albion found thy Waltz her way?

Borne on the breath of Hyperborean gales, From Hamburg's port (while Hamburg yet had mails), ')

Ere yet unlucky Fame - compelled to creep

To snowy Gottenburg - was chilled to sleep; ....

She came - Waltz came - and with her certain sets

Of true despatches, and as true Gazettes;

Then flamed of Austerlitz the best despatch, Which Moniteur nor Morning Post can match And - almost crushed beneath the glorious news Ten plays, and forty tales of Kotzebue's;

One envoy's letters, six composer's airs, And loads from Frankfort and from Leipsic fairs;

Meiner's four volumes upon Womankind, ${ }^{2}$ )

Like Lapland witches to ensure a wind;

Brunck's heaviest tome for ballast, ${ }^{3}$ ) and, to back it, Of Heynè, such as should not sink the packet.")

Fraught with this cargo - and her fairest freight, Delightful Waltz, on tiptoe for a Mate, The welcome vessel reached the genial strand, And round her flocked the daughters of the land.

Die unabhängigkeit eines deutschen fürsten, der seine eigenen münzen prägt, hatte ihm zwar einst als siebzehnjährigem sehr gefallen ( $L . J .$, I, s. 81); aber die träger solcher rechte stellte er ein andermal doch recht tief, indem er sich bei Miss Pigot nach deren hund Bran erkundigte und beifügte (L.J., I, s. 137):

By the immortial gods, Bran ought to be a Count of the Holy Roman Empire.

1) Kontinensalsperre.

2) Vgl. Poetry, I. 8. 489, anm. 3.

8) Vgl. das., s. 490 , anm. 1.

4) Vgl. das., s. 490, anm. 2. 
Später, im jahre 1814 (L. J., I, s. 408), bricht seine ganze, parteiische verachtung der deutschen fürsten wieder durch:

The thieves are in Paris ... and now the beasts - lion, bear, down to the dirtiest jackal - may all tear him .... He is in their rear - between them and their homes. Query - will they ever reach them?

Sein stolz bäumte sich - begreiflicherweise - auch auf, als sich aus einer nach dem tode der prinzels Charlotte, der hoffnung Englands, vom Courier aufgestellten liste ergab, dals some three hundred heirs für die englische krone da waren,

including the house of Wirtemberg, with that blackguard, Paul, 1) of disreputable memory, whom I remember seeing at various balls during the visit of the Mnscovites, etc., in $1814 \ldots$... (L.J., IV. 8. 184).

Hier mag auch folgende äufserung aus dem Don Juan $(\mathrm{X}, 60)$ platz finden:

... Germany, whose somewhat tardy millions

Have princes who spur more than their postillions.

Über die Schweiz, ihre bewohner usw. lauten seine urteile recht verschieden. So sagt er einmal sehr kräftig (L.J., V, s. 365):

Switzerland is a curst, selfish, swinish country of brutes, placed in the most romantic region of the world. I never could bear the inhabitants.

Dies bezieht sich wohl in erster linie auf die französische Schweiz, woriiber er ein andermal sagt (L.J., IV, s. 95): das gebiet von Genf, which is and is not Switzerland.

Seine betrachtungen und äufserungen über die Berner Oberland-bewohner sind mit dem erwähnten ausfall nicht zu vereinigen. Alles stimmte ihn im Oberland harmonisch, in dem

district famous for Cheese, liberty, property, and no taxes (L.J., III, s. 356).

Pretty music and excellent Waltzing; none but peasants; the dancing much better than in England ... some other dances in pairs and in fours, and very good (Brienz, 25. Sept. 1816; L.J., III. s. 361).

1) Prinz Paul von Württemberg, ein sohn des königs Friedrich; er war durch die zweite heirat des königs ein stiefsohn der Princess Royal von England geworden, und war im sommer 1814 mit in London gewesen. Er machte dort einen sehr schlechten eindruck. (L. J., IV. s. 184, anm. 3.) 
Nach seinen ansichten über den walzer in England das höchste lob! -

From Thoun to Bern, good road, hedges, villages, industry, property, and all sorts of tokens of insipid civilization (das., s. 362).

Die freundlichkeit der bewohner wie ihr äufseres gefielen ihm. Er wollte später seine natürliche tochter Allegra in der Schweiz unterbringen, damit sie dort erzogen werde und sich dort verheirate (L.J., V, s. 296). -

Er hat diese Schweizer eindrücke auch in Manfred verwertet. II. 1. 61 heifst es: ${ }^{1}$ )

Chamois Hunter: . What is it

That thou dost see, or think'st thou look'st upon?

Manfred: Myself, and thee - a peasant of the Alps -

Thy humble virtues, hospitable home,

And spirit patient, pious, proud, and free;

Thy self-respect, grafted on innocent thoughts;

Thy days of health, and nights of sleep; thy toils,

By danger dignified, yet guiltless; hopes

Of cheerful old age and a quiet grave,

With cross and garland over its green turf,

And thy grandchildren's love for epitaph!

This do I see $-\ldots$. .

Es war teilweise der nachhall seines schmerzes über die niederwerfung Napoleons, der als zerstörer des alten europäischen systems sein ideal gewesen war, was ihn später in inneren gegensatz zu den herren von Lombardo-Venetien, den Österreichern brachte. Er sah auch hier in ihnen die vertreter des alten systems, wie sie es in Byrons augen durch die mithilfe bei der wiedereinsetzung der Bourbonen gewesen waren. Polidoris ausweisung aus Mailand ${ }^{2}$ ) ging ihm persönlich freilich nicht nahe; aber mit der straffen österreichischen polizeigewalt war er doch sozusagen beim ersten atemzug in Wiener regierungsluft zusammengeraten.

Überhaupt erschien ihm die deutsche nation in der geschichte nirgends als kulturträger. ${ }^{3}$ ) Die spuren, die sie in Italien hinterlassen, waren zerstörung. Die Goten verab-

1) Abgesehen von I. 2. 47 ff.: "Hark, the note", etc.

2) S. 0. 8. 324 .

8) Vgl. w. u. über Friedrich den Grofsen. 
scheute er als zerstörer der antiken kultur in Italien, 1) trotz Gibbons lob Theoderichs des Grofsen.

Die besetzung Venedigs durch Österreich war ihm ein kummer, den man allerdings verstehen kann. Dals die alte dogenherrlichkeit durch Napoleon gestürzt worden, kam für Byron nicht in betracht: dals der Wiener kongrels sie nicht wieder aufgerichtet hatte, das empfand er als ein unrecht. Childe Harold, IV, 12 f.:

The Suabian sued, and now the Austrian reigns -

An Emperor tramples where an Emperor knelt;

Kingdoms are shrunk to provinces, and chains

Clank over sceptred cities; Nations melt

From Power's high pinnacle, when they have felt

The sunshine for a while, and downward go

Like Lauwine loosened from the monntain's belt;

Oh for one hour of blind old Dandolo!

Th' octogenarian chief, Byzantium's conquering foe.

Before St. Mark still glow the steeds of brass,

Their gilded collars glittering in the sun;

But is not Doria's menace come to pass?

Are they not bridled? ...

Better be whelmed beneath the waves, and shun,

Even in Destruction's deep, her foreign foes,

From whom Submission wings an infamous repose.

An den englischen konsul Hoppner in Venedig schrieb er (L.J., V, s. 281):

I gave to a musicianer a letter for you ... 't is a pity he can't make Venice dance away from the brutal tyrant who tramples upon it.

Grolsen spals machte es ihm, dals the admirable government of Vienna bei der prozession des patriarchen

prescribed, as a part of the pageant, "a Coach and four horses". To show, how very "German to the matter" this was, you have only to suppose our parliament commanding the Archbishop of Canterbury to proceed from Hyde Park Corner to St. Paul's Cathedral in the Lord Mayor's barge, or the Margate Hoy. ${ }^{2}$ )

Ferner waren es die Österreicher, die den durch die völkerwanderung zerstörten glanz des alten Rom nicht zu literatur.

1) Diese anschanung ist gemeingut in der damaligen englischen

2) L. J., IV, s. 65 . Vgl. anm. 1 daselbst. 
neuer, freier blüte kommen lassen wollten. Das italienische leben übte seinen vollen zauber auf Byron aus. Er fand hier, aufser der ungebundenheit, die ihm, im gegensatz zu England, schon im Orient $\mathrm{zu}$ sehr zugesagt hatte, auch ein erfreuendes mals von bildung. Aber besonders mutete ihn die eigenart der sitten an (L.J., IV, s. 407 f.):

Their life is not your life; you would not understand it: it is not English, nor French, nor German, which you would all understand.

I have lived long enough among them to feel more for them as a nation than for any other people in existence ( $L . J ., \nabla$, s. 10).

Um so grimmer halst er die unterdrücker (L.J., V, s. 10): I shall think it by far the most interesting spectacle and moment in existence, to see the Italians send the Barbarians of all nations back to their own dens ... No Italian can hate an Austrian more than I do; unless it be the English, the Austrians seem to me the most ohnoxious race under the Sky.

Und so geht es nun in den briefen der jahre 1820 und 1821 aus Ravenna fort. Die österreichische armee, welche den von den Carbonari vertriebenen könig von Neapel wieder einsetzen sollte, rückte heran:

I dislike the Austrians, and think the Italians infamously oppressed ... (L.J., V, s. 20). ${ }^{\text {) }}$

There are secret Societies all over the country as in Germans, who cut off those obnoxious to them, like the Free tribunals, -

eine anspielung auf den tugendbund oder die burschenschaftsbewegung, bezw. die ermordung Kotzebue's. ${ }^{2}$ )

We are here going to fight a little, next month, if the Huns don't cross the Po, and probably if they do: I can't say more now ... (L. J., V, 8. 68).

"Oh Jerusalem, Jerusalem!" the Huns are on the Po; but if once they pass it on their march to Naples, all Italy will rise behind them: the Dogs - the Wolves - may they perish like the Host of Sennacherib! (Das., s. 72). -

Die Österreicher waren damals natürlich als politische einheit für die zeitgenossen von den Deutschen noch nicht so streng zu scheiden, wie wir das heute tun. Überdies dienten viele Deutsche im österreichischen heere. Byron zählte aber auch tatsächlich (1821) die Österreicher zu den Deutschen; er

1) Vgl. Eberty, II, s. 194 ff., 214 ff., 222.

s) L. J., V, s. 57 . Vgl. oben, s. 325. 
sagt dort, wo er hervorhebt, dafs ihm deutsche frauen, dichtungen usw. gefallen (L. J., V, s. 172), ganz ausdrücklich, dafs er dies alles möge,

except the Austrians, whom I abhor, loathe, and I cannot find words for my hate of them, and should be sorry to find deeds correspondent to my hate; for I abhor cruelty more than I abhor the Austrians.

Wenn man ihm damals jenen brief vor augen gehalten hătte, worin er - 1809 - davon sprach, falls er seinen bẻsitz Rochdale nicht verkaufen könne, so wolle er in österreichische oder russische dienste treten! (L. J., I, s. 225.)

Da die Österreicher für ihn ein bestandteil der deutschen nation oder des deutschen bundes waren, so nennt er sie gelegentlich: Deutsche, auch: German Austrians (L.J., V, s. 245).

If the Germans pass the Po, they will be treated to a Mass out of the Cardinal de Retz's Breviary') (L.J., V, s. 78).

We are all in our "bandaliers" to join the "Highlanders if they cross the Forth", i. e. to crush the Austrians if they pass the Po. The rascals! - And that Dog Liverpool, to say their subjects were happy! what a liar! (L.J., V, s. 83).

Of Italy I can say nothing by the post: we are in instant expectation of the Barbarians passing the $\mathrm{Po}$; and then there will be a war of fury and extermination (Das., s. 107).

Im Dezember 1820 war der kongrefs zu Laibach zusammengetreten, wo die heilige allianz Österreich die expedition nach Neapel übertrug. Darüber äufsert sich Byron:

So the interests of millions are in the heads of about twenty coxcombs, at a place called Leibach (Das., 8. 165)!

Zur zeit des karnevals kam die nachricht, dafs die

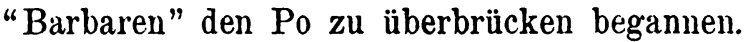

Half the city are getting their affairs in marching trim. A pretty Carnival! The blackguards might as well have waited till Lent. (Das., s. 183).

The Germans are on the $P_{0}$, the Barbarians at the gate, and their masters in council at Leybach ... and lo! they dance and sing and make merry, for to-morrow they may die (Das.).

Nehr und mehr begann Byron auch persönlich den kriegerischen zustand zu empfinden. Er schrieb wieder und

1) "Voilà le brériaire de M. le Coadjuteur", sagte M. de Beaufort, als er den griff des dolches, den de Retz aus vorsicht in der tasche trug, aus dieser hervorragen sah. Vgl. L. J., V, s. 78, anm. 1 . 
wieder um pulver nach England. Aber er erhielt es nicht. Da schreibt er in sein tagebuch (L. J., V, s. 189):

It appears that the Austrian brutes have seized my three or four pounds of English powder. The scoundrels! I hope to pay them in ball for that powder.

Die Österreicher überschritten den Po eher, als erwartet, (7. Februar). Byron setzte nun alle hoffnung auf einen kläftigen widerstand der Neapolitaner. Am 11. Februar schreibt er (Das., s. 201):

Heard a heavy firing of cannon towards Comacchio - the Barbarians rejoicing for their principal pig's birthday, which is tomorrow $\left.{ }^{1}\right)$ - or Saint day - I forget which.

Als die nachricht eintraf, dals die Neapolitaner beim vormarsch einige päpstliche karabineri getötet hatten, schreibt er (Das., s. 203):

It is a pity that the first blood in this German quarrel should be Italian.

The war approaches nearer and nearer ... Oh those scoundrels of sovereigns! Let us but see them beaten - let the Neapolitans but have the pluck ... of the German Protestants ..., the Swiss under Tell, or the Greeks under Themistocles - all small and solitary nations (except the Spaniards and the German Lutherans) . . (L. J., V, s. 206).

I do not speak of politics, because it seems a hopeless subject, as long as those scoundrels are to be permitted to bully states out of their independence (Das., s. 264).

Im April 1821 wurde, wie Byron berichtet, der versuch gemacht, einen mörder gegen ihn zu dingen, da er in einem bunde gegen "die Deutschen" stehe, die ihn halsten as a Coal-heaver, und da er verdächtigt wurde as the Chief of the Liberals. ${ }^{2}$ ) Byron liefs sich dadurch aber nicht erschrecken. Er übte zwar meist die vorsicht, nichts in seinen briefen zu schreiben, was ihn zum politischen märtyrer machen konnte; auch damit seine briefe die adressaten erreichten. Aber ergötzlich ist es, was er trotzdem Murray mitteilte:

I wonder if they can read them when they have opened them? If so, they may see, in my most legible hand, that I think them

1) Franz II. war am 12. Februar 1768 geboren.

2) L. J., $\nabla$, s. 287, 294, 297. (Nach letzterem brief wäre die aufreizende schrift gegen Byron schon im Februar umhergereicht worden.) 
damned scoundrels and barbarians, their emperor a fool, and themselves more fools than he; all which they may send to Vienna, for anything I care ... I suppose Providence will get tired of them at last, and show that God is not an Austrian (L.J., V. s. 129).

All letters pass through the Barbarians' inspection, and I have no wish to inform them of anything but my utter abhorrence of them and theirs. They have only conquered by treachery, however. (Das., s. 294).

Als die Österreicher ihre aufgabe in Italien gelöst hatten, schrieb Byron (Das., s. 404):

The real Italians are not to blame - merely the scoundrels at the Heel of the Boot, which the Hun now wears, and will trample them to ashes for their Servility.

Die gleiche stimmung gegen fremde eroberer Italiens finden wir in The Prophecy of Dante (1819) dichterisch ausgesprochen, z. b. II. 70 ff.:

Thou - Thou must wither to each tyrant's will:

The Goth hath been, - the German, Frank, and Hun

Are yet to come, - and on the imperial hill

Ruin, already proud of the deeds done

By the old barbarians, there awaits the new, Throned on the Palatine, while lost and won

Rome at her feet lies bleeding ...

Vers 83 ff.:

.... the nations take their prey,

Iberian, Almain, Lombard, and the beast

And bird, wolf, vulture, more humane than they

Are $;. .$. .

Vers $101 \mathrm{ff}$ :

Oh! when the strangers pass the Alps and $\mathrm{Po}$,

Crush them, ye Rocks! Floods whelm them, and for ever!

Why sleep the idle Avalanches so,

To topple on the lonely pilgrim's head?

Why doth Eridauus but overflow

The peasant's harvest from his turbid bed?

Were not each barbarous horde a nobler prey?....

Are the Alps weaker than Thermopylae?

Their passes more alluring to the view

Of an invader? is it they, or ye [Romans],

That to each host the mountain-gate unbar,

And leave the march in peace, the passage free?

What is there wanting then to set thee free? 
Vers $143 \mathrm{ff}$. :

And show thy beauty in its fullest light?

To make the Alps impassable; and we,

Her Sons, may do this with one deed - Unite.

Aufser einer äufserung betrübter teilnalıme gegenüber dem eingekerkerten Silvio Pellico (L. J., VI, s. 220; 1823) hört diese unerquickliche, wenn auch selbstredend menschlich begreifliche beschäftigung mit den Österreichern wieder auf, und wird durch weit erfreulichere beziehungen zu Deutschland abgelöst, nämlich das kapitel: Berühmtheit in Deutschland und Goethe. Ehe wir uns aber diesen und anderen geistigen beziehungen Byrons zu unserem vaterlande zuwenden, wollen wir ihn als reisenden im gebiete deutscher zunge begleiten.

\section{Reise am Rhein und ins Berner Oberland.}

Schon 1806 dachte Byron einmal daran, nach Deutschland und an die höfe von Berlin, Wien und Petersburg zu gehen, und zwar auf einige jahre (L. J., I, s. 96).

1814 wollte er mit Moore reisen. Damals aber war das ziel Italien und die Schweiz (das., III, s. 65). 1816 führte er diesen plan, der auch während seiner ehe wieder aufgetaucht war, für sich aus. Da ihm von der französischen regierung schwierigkeiten bereitet wurden, reiste er durch Belgien an den Rhein. ${ }^{1)}$

Leider haben wir keine briefe aus Deutschland von Byron selbst. Erst wochen- und monatelang später berichtete er von dieser reise an die seinen, und dann meist kurz und bündig. Daher war gerade über diese, für uns Deutschen besonders interessante reise in ihren einzelheiten recht wenig bekannt. Erst die veröffentlichung des tagebuches von Dr. Polidori hat plötzlich ein klares bild von der reise gegeben. Freilich hätte man schon früher einige schlüsse auf den eingeschlagenen weg machen können, da Byron, wenn auch ohne deutlichen hinweis, im Don Juan (X,60-62) einige fingerzeige gegeben hat: er lälst dort seinen helden Deutschland rasch von Berlin nach Dresden und von dort nach Mannheim durch-

1) F. Brie, Byrons Werke, I, s. 59. 
queren und den an schlössern reichen Rhein abwärts reisen, über Bonn mit dem Drachenfels und nach Köln. Dafs er Juan auf dem weg nach England von Dresden aus nach dem damals unbedeutenden Mannheim verpflanzt, ist eine erinnerung Byrons an seinen aufenthalt daselbst: Juan mufs die reise umgekehrt machen, wie Byron sie ausführte.

Die erwähnung der elftausend jungfrauen der hl. Ursula im Don Juan deutete darauf hin, dals er auch in Köln war:

St. Ursula and her eleven thousand virging were still exant in 1816 , and may so be yet, as much as ever.

Die stanzen im Don Juan aber lauten:

From Poland they came on through Prussia Proper,

And Königsberg, the capital, whose vaunt, Besides some veins of iron, lead, or copper, Has lately been the great Professor Kant. Juan, who cared not a tobacco-stopper About philosophy, pursued his jaunt To Germany, whose somewhat tardy millions Have princes who spur more than their postillions.

And thence through Berlin, Dresden, and the like, Until he reached the castellated Rhine: -

Ye glorious Gothic scenes! how much ye strike All phantasies, not even excepting mine! A grey wall, a green rnin, rusty pike, Make my soul pass the equinoctial line Between the present and past worlds, and hover Upon the airy confines, half-seas-over.

But Juan posted on through Mannheim, Bonn, Which Drachenfels frowns over like a spectre Of the good feudal times for ever gone, On which I have not time just now to lecture.

From thence he was drawn onwards to Cologne, A city which presents to the inspector Eleven thousand maiden heads of bone.

The greatest number flesh hath ever known.

Polidoris Diary erweist es als richtig, dals hier eigene erinnerungen Byrons verwertet wurden. Die reise vollzog sich folgendermafsen :

7. Mai: Überschreiten der preufsischen grenze hinter Battice. Ankunft in Aachen. 8. Mai: Ankunft in Köln. 10. Mai: bis Bonn. 11. Mai: bis Koblenz. 12. Mai: bis 
St. Goar. 13. Mai: bis Mainz. 14. Mai: bis Mannheim. 15. Mai: bis Karlsruhe. 18. Mai: bis Offenburg ${ }^{1}$ ). 19. Mai: bis Krotzingen. 20. Mai: bis Basel.

Wenn die schilderung Polidoris neben den eigenen äufserungen Byrons, die namentlich die gegend von Bonn, Koblenz und Andernach betreffen, in dieser studie ausführlicher verwertet wird, so findet das vielleicht seine rechtfertigung aus zweierlei gründen. Einmal sind auch die anderen reisen Byrons, soweit man sie genauer verfolgen kann, oft bis ins einzelne untersucht und geschildert worden. Zweitens spiegeln Polidoris bemerkungen und urteile gewifs vielfach seine gespräche mit Byron wieder; ihre eindrücke und beobachtungen werden ziemlich ähnlich gewesen sein. Es sind daher schon im vorigen abschnitt mehrfach Polidoris äufserungen mit herangezogen worden. Hier soll mehr die reise in ihren einzelheiten zusammengefalst werden.

In Aachen besichtigten sie den dom, der ihnen aber nach den schönen belgischen kathedralen wenig eindruck machte. In dem befestigten Jülich, das ihnen wohlgefiel, interessierte die reisenden besonders die stimmung der bevölkerung, die erst jüngst preufsisch geworden war. Um 11 uhr nachts kamen sie im "weitberühmten" Köln an, bedauernd, dafs sie die stadt bei der annäherung nicht sahen. Es fiel ihnen auf, dafs sie, ohne angehalten zu werden, durch die befestigungen eingelassen wurden. Da die gasthäuser überfüllt waren, klopften sie mehrfach vergebens an und übernachteten dann in der "Stadt Prag". Sie besichtigten am nächsten tage den dom, die kapelle der hl. Ursula, die St. Peterskirche. Dann meldete sich Polidori bei prof. Wallraff; ob Byron den gang durch die sammlungen des liebenswürdigen mäcens mitmachte, ist zweifelhaft. In Köln, wie auch an anderen orten, fanden sie mancherlei spuren von vandalismen, welche die Franzosen begangen hatten. Köln selbst erschien ihnen nicht gerade anmutig. Ebenso fanden sie an Bonn nichts reizvolles. Dann kamen sie vor Godesberg an dem s. g. Hochkreuz vorbei, nach Godesberg, und waren so dem Drachenfels gegenüber. Poli-

1) "Offenberg". Die deutschen und schweizerischen namen sind oft sehr verstummelt. 
doris freude an der schönen, gepflegten landschaft entspricht ganz Byrons eigenen anmerkungen und versen.

Ehe sie nach Koblenz kamen, wurden in Remagen die pferde gewechselt. Andernach gefiel ihnen mit seinen türmen, besonders aber Neuwied auf dem anderen ufer. Polidori spendet dem ort das hohe lob, dafs es die schönste und blühendste stadt sei, die sie seit Gent und Antwerpen gesehen hätten. Als sie das grabmal von Hoche erblickten, gingen sie zu fuls hin, um es zu betrachten. Die gegend nach Andernach begeisterte sie weniger, als die vorhergehende strecke. Als es dunkelte, sahen sie auch das grabmal Marceaus bei Koblenz. Auch Polidori berichtet, was sie im gasthof über den französischen general u. a. hörten (s. 83).

Die strophen des Childe Harold wiederzugeben, die das meiste enthalten, was Byron über den Rhein sagt, ist hier überflüssig. Die anmerkungen dagegen sind bisher noch nicht genügend gewürdigt worden und mögen daher hier platz finden und erläutert werden. Auch Polidoris bericht ist zur erklärung nützlich. (Poetry, II, s. 295 ff.):

1. The castle of Drachenfels stands on the highest summit of "the Seven Mountains", over the Rhine banks ${ }^{1}$ ); it is in ruins, and connected with some singular traditions. It is the first in view on the road of Bonn, but on the opposite side of the river; on this bank, nearly facing it, are the remains of another, called the Jew's Castle, and a large cross, commemorative of the murder of a chief by his brother. The number of castles and cities along the course of the Rhine on both sides is very great, and their situations remarkably beautiful.

Dazu ist folgendes zu sagen:

Dafs der Drachenfels nicht auf der höchsten erhebung des Siebengebirges liegt, hat schon E. H. Coleridge (Byron's Poetical Works II, s. 295) vermerkt.

Ein "Judenschlofs" oder eine "Judenburg" = the Jew's Castle gibt es bei Bonn nicht. Wohl aber liegt dem Drachenfels gegenüber die ruine Godesburg, rheinisch gesprochen "Jodesburg". Sollte der Schweizer Berger da einen argen blunder im übersetzen gemacht haben? Die gleichzeitige erwähnung des s. g. Hochkreuzes, das aus dem 14. jahrhundert

1) Vermerk Byrons im manuskript zu str. 1: "Written on the Rhine bank, May 11, 1816." 
stammt (1854 wieder hergestellt), und das dicht vor Godesberg an der stralse liegt (Baedeker), zwingt fast zu dieser annahme.

2. (zu str. LVI f.): The monument of the young and lamented general Marceau (killed by a rifle-ball at Alterkirchen [Altenkirchen] on the last day of the fourth year of the French Republic) still remains as described. The inscriptions on his monument are rather too long, and not required: his name was enough ... In the same grave General Hoche is interred ... A separate monument (not over his body, which is buried by Marceau's) is raised for him near Andernach, opposite to which one of his most memorable exploits was performed .... The shape and style are different from that of Marceau's, and the inscription more simple and pleasing.

"The Arny of the Sambre and Meuse

to its Commander-in-chief

Hoche."

This is all, and as it should be.

Das denkmal für Hoche ist ein Obelisk, dasjenige Marceaus eine pyramide. Es liegt am fufs des Petersberges bei Koblenz. -

3. (zu str. LVIII): Ehrenbreitstein, i.e. "the broad stone of honour", one of the strongest fortresses in Europe, was dismantled and blown up by the French at the truce of Leoben. It had been, and could only be, reduced by famine or treachery. It yielded to the former, aided by surprise. After having seen the fortifications of Gibraltar and Malta, it did not much strike by comparison; but the situation is commanding. General Marceau besieged it in vain for some time, and I slept in a room where I was shown a window at which he is said to have been standing observing the progress of the siege by moonlight, when a ball struck inmediatcly below it.

E. H. Coleridge hat darauf hingewiesen (Poetry, II, s. 297), dafs die festung erst 1799 den Franzosen übergeben wurde, während der friede von Leoben ins jahr 1797 fällt; ferner macht Coleridge darauf aufmerksam, dals die schleifung der festung nach dem frieden zu Lunéville (1801) stattfand. Sonst stimmt das, was Byron über die geschichte des Ehrenbreitsteins sagt. Er hatte es vielleicht aus seinem reiseführer, ${ }^{1}$ ) vielleicht auch aus einer anderen quelle: die stiefschwester Marceaus, Me Sergent, schrieb 1823 an Byron einen brief, worin sie ihm für seine worte über Marceau dankte

1) L.J., III, s. 382: "I refer you to the Guide-book." 
und ihm ein büchlein ihres mannes über denselben sandte (L. J., VI, s. 199, anm.). Darauf hin teilte Byron ihr mit, er habe das, was er geschrieben, von der wirtin des gasthauses erfahren, das am Rhein, der festung gegenüber, gelegen sei (Das., s. 199 f.). - Polidori sagt, es sei das hôtel Trois Suisses gewesen. Es stand ein gasthaus " $\mathrm{Zu}$ den Drei Schweizern" an der stelle des heutigen hôtels Bellevue. Fast erstaunlich ist es, dafs man den reisenden nur sagte, dals Marceau dort gewohnt hatte, nicht aber, dals auch der herzog von Braunschweig, Blücher und Wellington dort zu gast gewesen waren. ${ }^{1}$ )

Koblenz interessierte sie ganz besonders. Der prächtige blick auf den strom mit der schiffbrücke, der stolze Ehrenbreitstein auf der anderen seite begeisterte sie. Sie fuhren in einem wagen zunächst zum grabmal Marceaus. Dann fuhren sie zu der Karthause im süden der stadt, deren trümmer damals noch standen. Der Kalvarienberg zog ihre aufmerksamkeit auf sich, ebenso wie die zahlreichen kruzifixe in der ganzen gegend ihr erstaunen hervorriefen. Die betenden bauern am Kalvarienberg werden von Polidori bemerkt und ihre tracht beschrieben; ferner auch die offiziere mit ihren kriegsorden. Es klingt fast nach Byron, wenn Polidori scherzt (s. 85).

Crosses given apparently with as profuse a hand to the soldiers as to the roadside.

Sie fuhren zur schiffbrücke und gingen auf den Ehrenbreitstein, dessen zerstörung sie ebenso fesselte wie del prachtvolle blick iiber die gegend und ihren reichtum. Sie ruderten nach Koblenz zurück und setzten die reise alsbald fort. Vor St. Goar wurde noch besonders der Rheinstein bemerkt. Die enge des Rheintals löste offenbar die höchste begeisterung aus (Polidori, s. 86):

Indeed the river reaches foot to foot - splendid, splendid, splendid.

Auch die fahrt nach Bingen, mit den friedlichen weinbauern bei ihrer arbeit, den wäldern und der schönen ebene fand vollen beifall. Ebenso die gute strafse, die Napoleon

1) Mitteilung des herrn archivrat Richter in Koblenz, nach dem Rheinischen Antiquarius, 1. Abt. I. Byrou wird dort nicht als gast genannt. 
angelegt hatte, wie denn Napoleons wirken ihnen überhaupt allenthalben entgegentrat. Die vielen burgen, das lied des postillions, alles gefiel ihnen.

Mainz, wo ihnen die verschiedenen kontingente der besatzung auffielen, erklärt Polidori nun, wie vorher Neuwied, für die schönste stadt seit Gent. Am folgenden tage (14. Mai) besuchten sie den dom und fuhren nach Mannheim, von dort am 15. nach Karlsruhe. Da Polidori erkrankt war, blieben sie dort über zwei tage. Nunmehr wird Karlsruhe als the neatest town we have yet met with bezeichnet. Sie fuhren in der stadt und der umgebung umher, so gut Polidoris zustand es erlaubte. Er wurde von dem früheren Lord Mayor von London, Sir Claudius Stephen Hunter, aufgesucht, der gehört hatte, Polidori liege im sterben. ${ }^{1}$ ) Der Mayor gab ihnen allerhand winke und einen reiseführer.

Die oberrheinische tiefebene mit ihren bäumen, ihrer trachtenreichen bevölkerung und den gelbröckigen postillionen mutete die reisenden wieder sehr an, wie auch, nach dem quartier in Offenburg, die dunstigen Schwarzwaldberge und das Freiburger münster. Nachdem sie in Krotzingen (südlich von Freiburg) übernachtet, führte sie die stralse über eine anhöhe, und hier erblickte Byron zum ersten male die Alpen (19. Mai) und dazu den Jura. Dann kamen sie nach Basel (Basle).

Byron falste all dies zusammen in die worte $(L . J$., III, s. 334):

My way through Flanders, and by the Rhine, to Switzerland, was all I expected, and more.

Noch 1821 schrieb er in sein tagebuch (L.J., V, s. 172):

I like all ... that I have seen on the Rhine of their country and people.

Nicht nur verwies er, wie auch schon im Orient, auf den reiseführer, sondern es mag für seine schweigsamkeit in dieser zeit auch die tatsache mafsgebend gewesen sein, dafs Murray durch ihn an Polidori das angebot hatte ergehen lassen, ihm

1) Polidori erzählt: "He took care to tell us he was a great friend of the Grand Duke, who had sent his groom of the stole in search of lodgings for the worthy Mayor." Rossetti möchte hier statt Mayor: "Mylor" lesen. Wenn Sir C. Hunter "a great friend of the Grand Duke" war, so ist die lesart Mayor doch wohl die richtige. 
für $£ 500$ ein tagebuch von der reise zu verfassen. So mochte Byron mitteilungen in die heimat für überflüssig halten, wie damals, als er aus Smyrna an seine mutter schrieb (L.J., I, s. 258):

I keep no journal, but my friend Hobhouse scribbles incessantly.

Die reise von Basel nach Genf weist folgende nachtquartiere auf: Am 20. Mai: Basel. Am 21. —? Am 22. —? 1) Am 23.: Murten ("Krone"). Am 24.: Lausanne. - In Basel machten sie noch am 20. abends einen gang auf die Rheinbrücke und auf "einen hügel in der stadt", vermutlich beim münster. Am folgenden tage besuchten sie zunächst ein panorama von Thun und eine bildergalerie des betreffenden malers. Polidori erwähnt auch den zerstörten totentanz (s. 91); vgl. Don Juan, XV, 39.

Als sie von Basel südwärts fuhren, gefiel ihnen das hügelige land sehr. ${ }^{2}$ ) Sie bewunderten des abends die aussicht von einer anhöhe aus, ehe sie sich im gasthaus niederliefsen. Dort sahen sie die leute kegel spielen. - Über die Jurahöhen ging es nach Solothurn. Unterwegs interessierten sie sich wieder für die trachten und die häuser mit den weitausladenden dächern. Solothurn mit seinen stadtmauern und der "sauberen kirche mit brunnen davor" wird besonders gerühmt.

Ehe sie nach Bern kamen, sahen sie am folgenden tage wieder die Alpen. Die lage von Bern und die strafsen mit den lauben entzückten sie. Sie hielten dort mittagsrast. Als sie durch die baumreiche landschaft nach Murten zu fuhren, zeigte sich ihnen der Jura in seiner herrlichkeit, with snowy hair and cloudy night-caps (s. 92), wobei sie sich den ganzen weg stritten, ob die wolken berge oder die berge wolken seien. Was Polidori über das schlachtfeld und über Aventicum sagt, ist eine ergänzung zu Childe Harold, III, $43 \mathrm{ff}$. Byron fand, dafs das Amphitheater in Aventicum grölser sei als gewöhnlich. Sie betrachteten alles aufs genaueste. Doch fanden sie die inschrift auf Julia Alpinula, die Matthison erwähnt, nicht. Diese bemerkung ist interessant, insofern man

1) Zwischen Solothurn und Bern. Polidori macht hier nur einen strich.

2) "Passed through Lipstadt"; vermutlich Liestal. 
aus Byrons note $15 \mathrm{zu} C h$. $H$. schliefsen mulste, diese Inschrift habe ihn an ort und stelle sehr ergriffen. Bei der weiterfahrt über Payerne und das schmutzige Moudon fielen ihnen die buben auf, die ihre ziegen "ganz in antiker weise" führten. In Moudon erfrischten sie sich und gelangten abends nach Lausanne. -

Byrcns ausflug ins Berner Oberland ist öfters behandelt worden. Nur der vollständigkeit wegen sei hier vorerst wiederholt, dafs er ihn über den Col de Jaman, Montbovon, durch das Simmental, nach Thun, Interlaken, Lauterbrunnen, die Wengernalp, Grindelwald, die kleine Scheideck, den Reichenbachfall und Brienz, und von da zurück nach Interlaken, Thun, Bern, Freiburg, an den Neuenburger See, nach Yverdun und zurück nach Diodati führte (17.-29. Sept. 1816).

Polidori war zuvor von Byron wegen der unbequemen art des doktors entlassen worden, und dieser tröstete sich auf einer wanderung, die ihn zunächst den gleichen weg führte, wie danach Byron. Polidoris tagebuch über diese einsame wanderung gibt jedoch keine anhaltspunkte für Byrons reise. Er verzeichnet nur kurz eine begegnung mit Byron und Hobhouse zwischen Grindelwald und Interlaken (22. September), worüber er lakonisch bemerkt: we saluted (s. 158).

Was nan Byrons Oberlandreise betrifft, so finden wir in Broughton's Recollections etc. einiges, was zur ergänzung unserer bisherigen kenntnisse dient, und es erscheint vielleicht auch nicht als ganz überflüssig, einigen bemerkungen aus Byrons tagebuch, seinen spuren folgend, aufmerksamkeit zu schenken.

19. September (L. J., III, s. 353 ff.):

At Mont Davant we breakfasted.

Mit diesem Mont d'Avant ist wohl sicherlich der heute les Avants genannte punkt gemeint $(985 \mathrm{~m})$, wo sich jetzt ein gröfserer gasthofkomplex befindet. Die schöne strafse, die in jüngster zeit bis auf die palshöhe fortgesetzt worden ist, war damals noch nicht vorhanden, weshalb der sehr steile anstieg für die maultiere und ihre reiter gleich mühsam war.

At the approach of the summit of Dent Jamant dismounted again with $H$ [obhouse] and all the party. Arrived at a lake in the very nipple of the bosom of the Mountain; left our quadrupeds with a Shepherd, and ascended further... I scrambled on and upwards. 
$H$. went to the highest pinnacle; I did not, but paused within a few yards (at an opening of the Cliff).... The whole of the Mountain superb. (Byron.)

Was Byron the summit of Dent Jamant nennt, ist der Col de la Dent de Jaman (1512 m), ein ziemlich breiter pals; von Montreux kommend, liegt der kleine see rechts in einer mulde, und darüber erhebt sich der Dent de Jaman (1879 m), der das landschaftsbild von Montreux und Glion mit seiner charakteristischen form beherrscht. Vom Col steigt man in einer guten stunde hinauf. Es ist ein steiler pfad, und da Byron der obersten spitze tatsächlich so nahe kam, wie er angibt,1) so war dieser abstecher an sich für ihn eine ganz eigenartige leistung. $\mathrm{Da}$ der weg abwärts nach Montbovon teilweise auch recht steil ist, und da der anstieg zum Col schon mehrfaches scrambling und tumbling mit sich gebracht hatte, versteht man Byrons seufzer: I am so tired, den er in Montbovon dem tagebuch einverleibte, um dann zu wiederholen: ourselves fatigued.

Hobhouse sagt (II, s. 19):

"The whole scene gave us quite a new idea of Alpine life. Byron observed that the gloomy green pastures, with the cottages aud cows in these heights, were like a dream; something too brilliant and wild for reality."

Descended to Montboron; pretty scraggy village, with a wild river and a wooden bridge. (Byron.)

Der flufs ist die Saane, die sich ober- und unterhalb des ortes $(795 \mathrm{~m})$ wild durch enge cañons drängt. $\left.{ }^{2}\right)$ Etwa eine viertelstunde unterhalb des dorfes führt eine malerisch gelegene gedeckte holzbrücke hoch über den flurs weg. Da $H$. went to fish, so ist es nicht unmöglich, dals Byron ihn begleitete, und sie so an diese brücke gelangten: im ort selbst ist jedenfalls heutzutage keine holzbrücke von bedeutung $\mathrm{zu}$ finden. - Der hauptgasthof ist das Hôtel de Jaman, ein älterer steinbau an der landstrafse; dies dürfte das nachtquartier der reisegesellschaft gewesen sein.

1) Hobhouse, a. a. o., II, s. 19: "Berger got up, but Lord Byron halted twenty yards below."

2) S. 356: "The bed of the river very low and deep, between immense rocks, and rapid as anger." (Byron.) 
20. September (Das., s. 355 ff.) ${ }^{1}$ ):

A mountain with enormous Glaciers to the right - the Kletsgerberg; further on, the Hockthorn - nice names - so soft! Stockhorn ${ }^{2}$ ), I believe, very lofty and craggy ... no Glaciers on it. (Byron.)

Mit dem Kletsgerberg dürfte der Geltengletscher am Wildhorn oder dieses selbst gemeint sein, das Byron eben einfach als ein "gletscherberg" bezeichnet wurde. Es bleibt nach Saanen sichtbar, bis die strafse sich gegen den Thuner see senkt. Alsdann erscheint das Stockhorn, zwischen dem Simmental und Thun gelegen.

Passed the boundaries out of Vaud into Bern Canton; French exchanged for a bad German. (Byron.)

Diese bemerkung mülste in einer genauen schilderung vor der vorigen stehen: die grenze ist nahe der ruine Vanel bei Saanen, und wird heute durch einen grenzstein neueren datums bezeichnet.

Die strafse senkt sich hier dicht zum flufs hinab. Dort mag es gewesen sein, wo

H. went to fish - caught none. Strolled to river: saw boy and kid; ... kid could not get over a fence, and bleated piteously; tried myself to help kid, but nearly overset self and kid into the river. (Byron.)

21. September (Hobhouse, s. 20) frühstückten sie in Weilsenburg (Simmental).

22. September (L. J., s. 357 f.):

Passed a rock; inscription -2 brother - one murdered the other; just the place for it. (Byron.)

Die inschrift ist - auf eine neue marmortafel übertragen - noch vorhanden, nicht weit oberhalb Wilderswyl bei Interlaken im tal der Lütschine. Die inschrift lautet:

Hier war der freiherr von Rothenfluh von seinem bruder erschlagen.

Der heimatlose mörder, 48 jahre in bann gelegt, beschlofs im fernen auslande den einst mächtigen stamm.

Ehe Byron diesen punkt erreichte, war er in einiger entfernung an dem schlosse Unspunnen vorbeigefahren, das als

1) Für diesen tag fehlt ein eintrag bei Hobhouse.

2) Ich folge hier der schreibung Moore's. Prothero wiederholt: "Hockthorn, I believe". 
das schlo[s Manfreds angesehen wird. ${ }^{1}$ ) Von einer gotischen galerie (Manfred, I, 1), von einem grofsen saal - $A \mathrm{Hall}-$ (III, 1) ist an ort und stelle nichts zu bemerken. Auch ist die ruine von der strafse aus keineswegs in die augen fallend. Das tal ist noch ziemlich breit. Auf der burg selbst ist Byron nicht gewesen, und es mögen ihm bei den angaben für Manfred's Castle auch noch andere Schweizer schlösser vorgeschwebt haben, die·er näher kennen gelernt hatte. ${ }^{2}$ )

Hobhouse nennt die fahrt nach Lauterbrunnen "unbeschreiblich", und bemerkt:

"We admired everything as we advanced into these secluded regions."

Lodge at the Curate's. (Byron; in Lauterbrunnen.)

Prothero hat vermerkt, dafs das damalige pfarrhaus in Lauterbrunnen noch steht. Es ist ein behaglicher bau aus stein, in einem garten abseits der stralse, und macht mit seiner loggienartigen galerie einen einladenden eindruck:

Swiss Curate's home very good indeed .... It is immediately opposite the torrent I spoke of. (Byron.)

23. September (L. J., III, s. 359 f.):

Ascended the Wengen Mountain; at noon reached a valley on the summit; left the horses ... and went to the summit, 7000 feet (English feet) above the level of the sea ... From where we stood, on the Wengen Alp, we had all these [Jungfrau etc.] in view ... The side we ascended was (of course) not of so precipitous a nature; but on arriving on the summit, we looked down the other side upon a boiling sea of cloud, dashing against the crags on which we stood (these crags on one side quite perpendicular). (Byron.)

Dicht bei dem hôtel Wengernalp $(1877 \mathrm{~m})$, ist ein unbedeutender lügel, die Wengernalp, worauf die Schweizer fahne weht, und welcher "Byronhöhe" genannt wird. Dieser punkt kann jedoch, nach Byrons beschreibung, nicht der berg sein, den Byron und Hobhouse bestiegen. Vielmehr kommt der angabe

1) Vermutlich zufolge Murray's Handbook of Switzerland. Diese notiz verdanke ich herrn Prof. Dr. G. Schirmer in Zürich.

2) Byron sah - abgesehen von Chillon - auch bei Clarens verschiedene wohlerhaltene schlösser und besuchte das hübsche Chatelard mit Shelley (Buxton Forman, VI, s. 182). Auch in Rougemont (bei Saanen) ist ein wohlerhaltenes schlofs, umgeben von alpenhöhen. Ferner erwähnt Hobhouse (II, s. 20), dafs sie das schlofs Wimmis am fufs des Niesen sahen. 
Byrons in bezug auf die höhe $(7000$ fufs $=2128 \mathrm{~m})$ das Galtbachhorn $(2319 \mathrm{~m})^{1}$ ) am nächsten, während die schilderung der örtlichkeit gut auf das Lauberhorn $(2475 \mathrm{~m})$ pafst, das am besten von der kleinen Scheidegg aus zu besteigen ist. Es ist also anzunehmen, dafs Byron einen dieser aussichtspunkte erstiegen hat, und dies ergibt sich auch aus Hobhouse's angaben. Er erzählt, dals sie die pferde grasen lielsen und einen gipfel, Malinetha genannt (?), in fünfzig minuten erstiegen. Er schildert die genufsreiche aussicht ähnlich wie Byron, und fügt hinzu (s. 21):

We lay down a short time contemplating this glorious scene, and wrote our names on a bit of paper, which we bid under a small stone near a blue flower. Here one's spirits seemed lighter, one's head more clear.

Dafs Byron während seines kurzen aufenthalts auf der palshöhe "die Alpenszenen" des Manfred geschrieben habe, ${ }^{2}$ ) ist legende und geschäftsreklame:

Got down to our horses again; eat something; remounted. (Byron.)

Es ist nicht einmal $z u$ erweisen, dals die reisenden einen gasthof betraten, und ob es sich nicht um die kleine Scheidegg handelt.

Wenn man E. H. Coleridge zustimmt, dafs it may be taken for granted that the composition of the first two acts beiongs to the tour of the Bernese Alps, ${ }^{3}$ ) so ist doch über den ort der abfassung nichts zu ermitteln. Überdies fügt Coleridge hinzu -: or to the last days at Diodati. Nicht einmal dies ist sicher. ${ }^{4}$ )

26. September (L. J., s. 362 f.):

Bought a dog ... He hath no tail, and is called "Mutz", which signifies "Short-tail": he is apparently of the Shepherd dog genus!

Mutz bedeutet: Bär; die Berner werden Mutz genannt.

1) Bädekers Schweiz. 25. aufl., 8. 154.

2) So steht zu lesen $\mathfrak{u}$. a. in Meyers Konversationslexikon, 1908, unter Wengernalp.

3) Byron's Poetical Works, IV, s. 79.

4) Über Varnhagens theorie in De rebus quibusdam usw. habe ich in den Engl. Studien ( $\mathrm{XLV}$, s. $160 \mathrm{ff}$.) einiges gesagt. - Die angabe von Hobhouse (24. Sept.): "Set out from Lauterbrunnen" ist verwirrend. Es mufs: Grindelwald heifsen. 
Auch über ihre reise durch das Wallis zum Simplon finden sich nähere angaben bei Hobhouse (II, s. $28 \mathrm{ff}$.). Die quartiere waren: 6. Oktober: St. Maurice (vgl. den abt von St. Maurice in Manfred); 7.: Sitten; 8.: Brieg; 9.: Simpeln. Die schilderung bietet für uns nichts von bedeutung.

Noch dreimal tauchte bei Byron der gedanke auf, sich wieder über die Alpen zurückzubegeben, wobei er das erste mal (als seine freunde in Ravenna, die gräfin Guiccioli und deren verwandte, aus dem kirchenstaat ausgewiesen wurden) wohl nur an die welsche Schweiz dachte ${ }^{1}$ ); die anderen male wäre er aber, wenn er diese pläne ausgeführt hätte, wieder aufs engste mit deutschem wesen in berührung gekommen: erstens hatte er ende 1819 die absicht (L.J., IV, s. 382), durch Tirol nach Calais und England zu reisen; und zweitens sagte er Goethe in dem denkwürdigen brief an diesen (L.J., VI, s. 237) zu, dafs er, falls er je aus Griechenland zurückkehre, Weimar besuchen wolle. -

1) L. J., V, s. 365 : "I never could bear the inhabitants, and still less their English visitors .... Upon hearing that there was a colony of English all over the cantons of Geneva, etc., I immediately gave up the thought."

(Schlurs folgt.)

Strassburg.

M. Eimer. 